\title{
Non-technical skills and traits needed to be career-ready graduates as perceived by agribusiness employers and recruiters
}

Thomas H. Brand III

West Virginia University

Follow this and additional works at: https://researchrepository.wvu.edu/etd

\section{Recommended Citation}

Brand, Thomas H. III, "Non-technical skills and traits needed to be career-ready graduates as perceived by agribusiness employers and recruiters" (2005). Graduate Theses, Dissertations, and Problem Reports. 2161.

https://researchrepository.wvu.edu/etd/2161

This Thesis is protected by copyright and/or related rights. It has been brought to you by the The Research Repository @ WVU with permission from the rights-holder(s). You are free to use this Thesis in any way that is permitted by the copyright and related rights legislation that applies to your use. For other uses you must obtain permission from the rights-holder(s) directly, unless additional rights are indicated by a Creative Commons license in the record and/ or on the work itself. This Thesis has been accepted for inclusion in WVU Graduate Theses, Dissertations, and Problem Reports collection by an authorized administrator of The Research Repository @ WVU. For more information, please contact researchrepository@mail.wvu.edu. 
Non-technical Skills and Traits Needed to be Career Ready Graduates as Perceived by Agribusiness Employers and Recruiters

Thomas H. Brand III

Thesis submitted to the Davis College of Agriculture, Forestry, and Consumer Sciences at West Virginia University in partial fulfillment of the requirements

for the degree of

\author{
Master of Science \\ in \\ Agricultural and Environmental Education
}

Stacy A. Gartin, Ph.D., Chair

Harry N. Boone, Jr., Ph.D.

Deborah A. Boone, Ph.D.

Division of Resource Management

Morgantown, West Virginia

2005

Keywords: Communications, Employment skills, Interviewing, Agricultural Education, Agribusiness, Agriculture, Education 


\section{ABSTRACT \\ Non-technical Skills and Traits Needed to be Career Ready Graduates as Perceived by Agribusiness Employers and Recruiters}

Thomas H. Brand III

The purpose of the study was to determine the skills needed by students of the Davis College of Agriculture, Forestry, and Consumer Sciences to secure employment after graduation. The population consisted of 211 agribusiness employers who have attended the College's Biannual Career Fairs. A descriptive research design was used for this study. A major finding of this study was employers rated graduates based on means as somewhat prepared or not prepared in several communication skills, business skills and business abilities. Employers also rated Davis College graduates in general to college graduates in preparation level for entry level employment. There were various skills important to employers for the success of graduates in entry level positions. These skills included, but were not limited to: effective verbal skills, oral communication, listening, following instructions, time management, planning and completing projects, professional behavior, leadership, and professional appearance. 


\section{DEDICATION}

To my family and friends: For always believing in my abilities and potential.

To my Grandfather (Papaw): For the example you provided and the pride you always showed in me.

To my wife, Sylvia, and my son, Thomas: For all the sacrifices you endured and the support you had for me.

I couldn't have done it without you. 


\section{ACKNOWLEDGEMENTS}

To the recruiters and employers of Davis College of Agriculture, Forestry, and Consumer Sciences who took time out of their schedules to share their thoughts and ideas which enabled completion of this project, I extend sincere appreciation for making this possible.

To my committee as a whole, an incredible group of educators and professionals who contributed many hours making sure this project was completed; I am forever indebted to you. There is no other group of faculty I would want to collaborate and be associated with then you.

To Dr. Stacy A. Gartin, your belief and trust in my abilities and efforts have been an inspiration throughout this entire process. I would have never dreamed of loving teaching and the education profession as much as I do, and I have learned it all from you. Your passion for educating and making a difference in people's lives is remarkable. There are so few people in the profession who lead by example and "walk the talk", but you do and for that I commend and honor you. I can not begin to thank you for the numerous ways you have touched my life and the contributions you have made to my growth and development. I am looking forward to our future friendship and the road that lies ahead. Thank you for being a part of my life.

To Dr. Harry Boone, I certainly could not have even begun this project and journey without you. The foundation of my graduate education and this thesis was placed and built by you and your amazing teaching abilities in research and data. Your availability to me throughout the process for ideas and, of course data analysis, was 
remarkable and priceless. The ease and mastery with which you teach your students is above and beyond all others. Thank you for dedicating your passion and skills in research to this profession. We are better students and researchers because of you.

To Dr. Deborah Boone, for the contribution and work you have done on this project, I am very grateful. Thank you for having the same passion and dedication as your colleagues in this department. You were the perfect compliment to my committee, bringing the team full circle. I applaud your efforts in educating and advising students, and certainly for keeping me on track through this whole project. I could not have done it without you.

To Alice Compton, the rock and support of the Agricultural and Environmental Education department, where would I be without you? This project would have never been completed if it weren't for your contributions and efforts. Thank you for all your help.

To my family, can you believe I finally did it? Even when I doubted myself you were all always silently pushing and supporting me. To my wife, Sylvia, thank you for your sacrifices which allowed this to happen, I will forever be grateful. To my son, Thomas, the light of my life, everything I have done has been for you and with you in mind, I am forever proud of you and what you have brought to my life. To my Mom, there is no question I could not have accomplished any of this without you. I am forever grateful and words can not begin to thank you for all that you have done for me to get me to this point. To my Dad and Melana, thank you both for always believing in me and knowing this venture was going to benefit me beyond words even when I didn't. Your words of support and understanding and your guidance will always be with me. 
To my friends, I am truly the luckiest person in the world to have known you all and had you in my life. Your unwavering support has been my strength through all my efforts. I thank each and every one of you for your friendship and trust. I could never begin to repay all that you have been to me. My fellow teaching assistants, you have given me daily strength and encouragement all along the way. I thank you for your friendships and partnerships and for always keeping me on track.

The many people throughout my life that have influenced who I am today, I could never begin to list or name. I have been blessed by each and every one of you and I am who I am today because of you all. 


\section{TABLE OF CONTENTS}

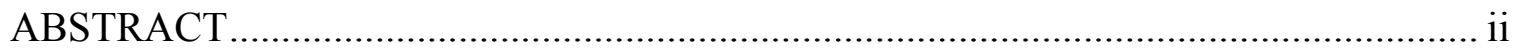

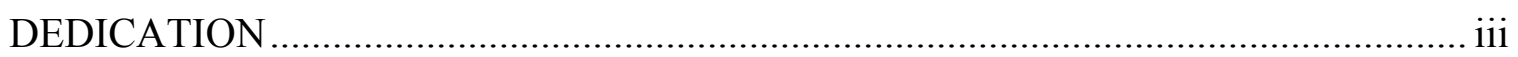

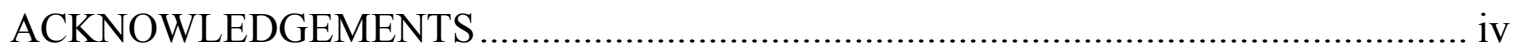

TABLE OF CONTENTS................................................................................... vii

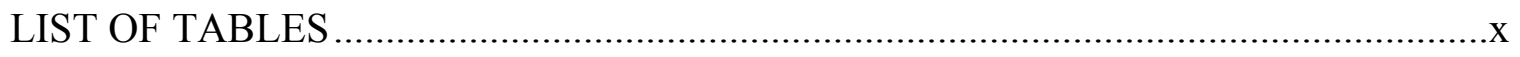

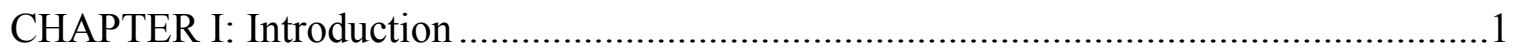

Problem Statement ...............................................................................

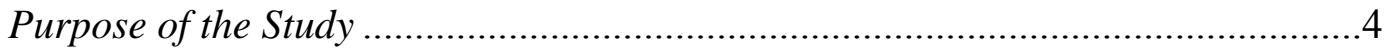

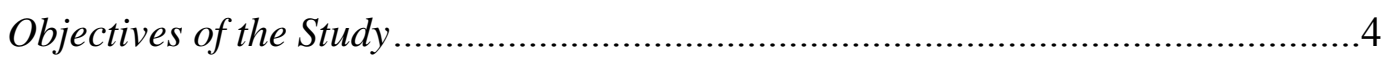

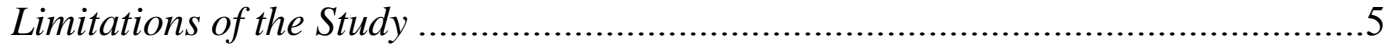

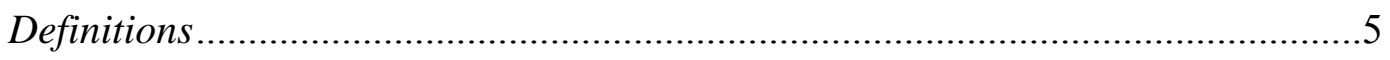

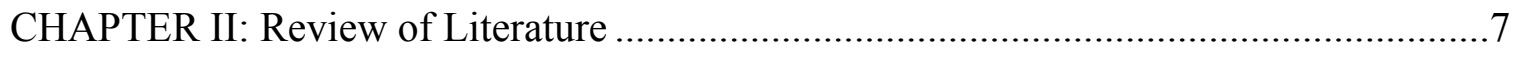

Need for Change and Review of Curriculum ..................................................

Assessing Employer Needs and Desires .......................................................

Defining Employability Skills ...............................................................

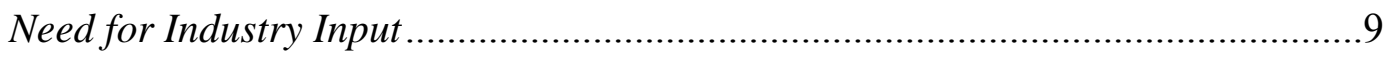

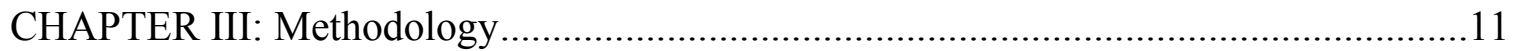

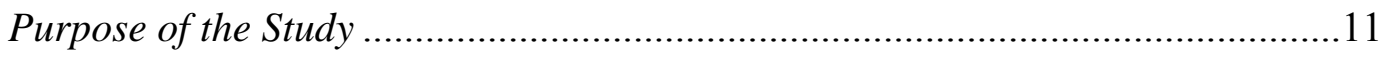

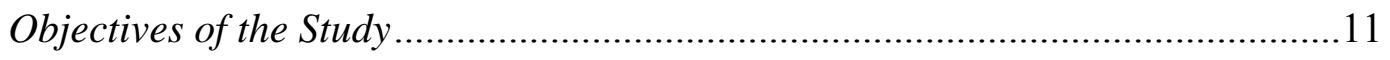

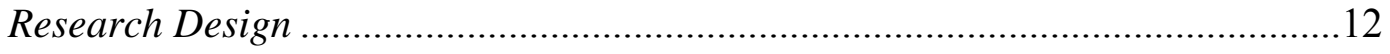

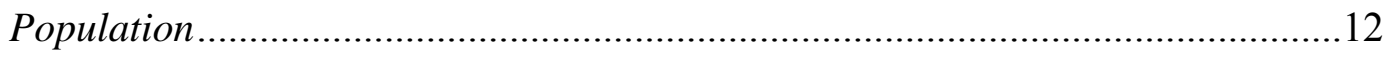

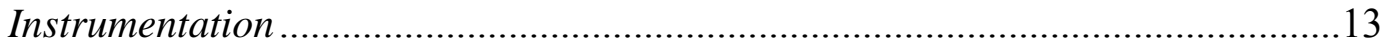


Data Collection Procedures ...........................................................................15

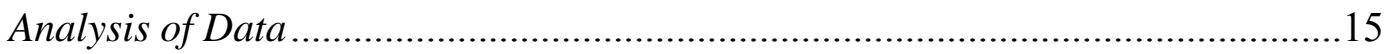

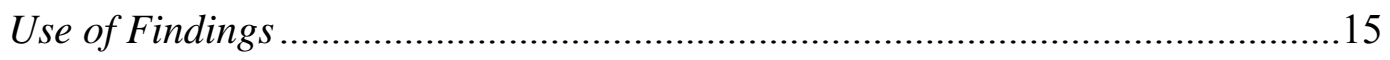

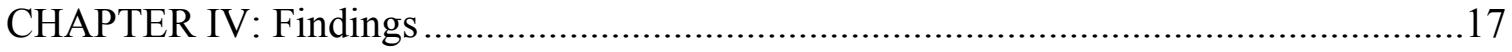

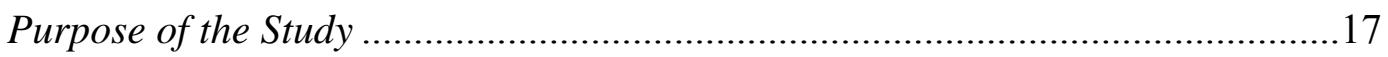

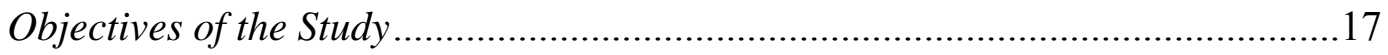

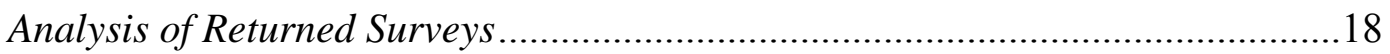

Items of Importance for Successful Interviewing .................................................19

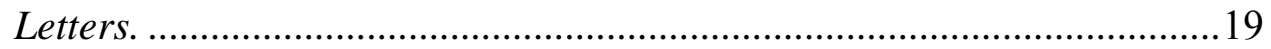

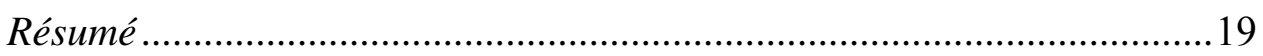

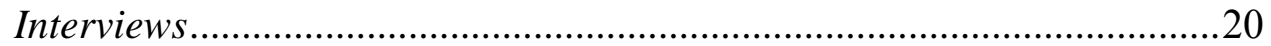

Items of Preference for Initial Consideration for an Interview ..............................22

Personality Skills and Traits Important to Success ...........................................23

Importance of Experiences to Success of New Employees ...................................25

Preparation of Graduates in Communication Skills.............................................26

Preparation of Graduates in Business Skills ....................................................29

Preparation of Graduates in Business Abilities.....................................................

Preparation of Davis College Graduates Compared to College Graduates..........33

Importance of Skills and Traits to Entry Level Employment .................................35

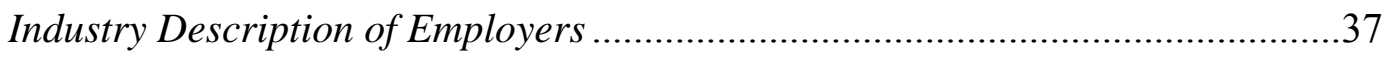

Majors Employers Have Hired or Would Consider ..............................................39

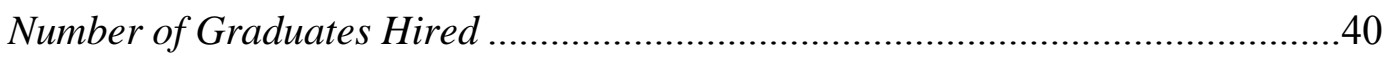

Preparation Level of Davis College Graduates for Entry Level Employment .......41 
Summary of Research Findings .......

CHAPTER V: Summary, Conclusions, and Recommendations ......................................44

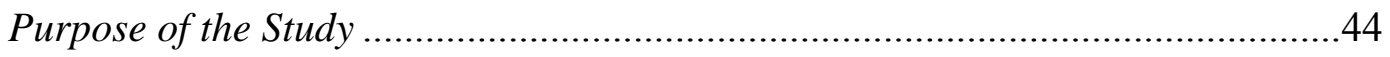

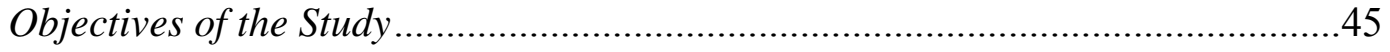

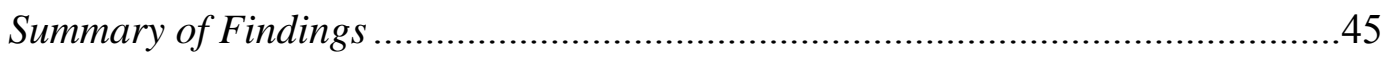

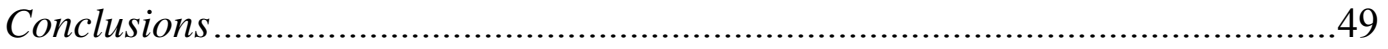

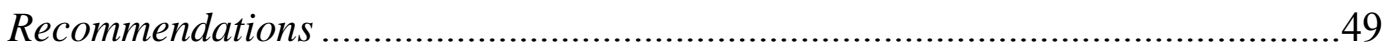

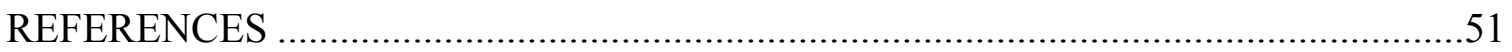

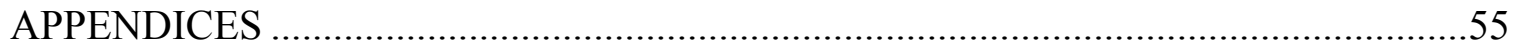

APPENDIX A: Career Fair Interview Questions ................................................56

APPENDIX B: Cover Letter to Research Population...............................................59

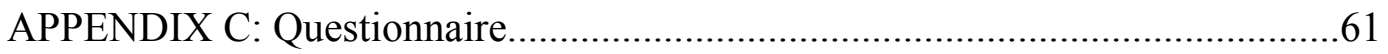

APPENDIX D: Follow-up Cover Letter.........................................................68

APPENDIX E: Courses Beneficial to Students ....................................................

APPENDIX F: Comments for All Divisions ......................................................72

APPENDIX G: Comments for Division of Resource Management .......................75

APPENDIX H: Comments for Division of Family and Consumer Sciences .........78

APPENDIX I: Comments for Division of Division of Forestry ............................80

APPENDIX J: Comments for Division of Animal and Veterinary Sciences .........83

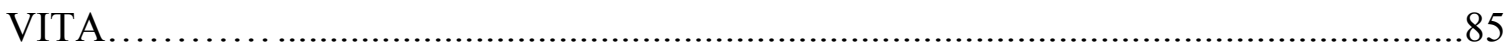




\section{LIST OF TABLES}

Table 1 Items of Importance for Successful Interviewing ..........................................21

Table 2 Items of Preference for Initial Consideration .............................................23

Table 3 Personality Skills and Traits Important to Success ......................................24

Table 4 Importance of Experiences to Success of New Employees .............................27

Table 5 Preparation of Graduates in Communication Skills....................................28

Table 6 Preparation of Graduates in Business Skills ................................................30

Table $7 \quad$ Preparation of Graduates in Business Abilities.............................................32

Table 8 Preparation of Davis College Graduates Compared to College Graduates ...34

Table 9 Importance of Skills and Traits to Entry Level Employment ..........................36

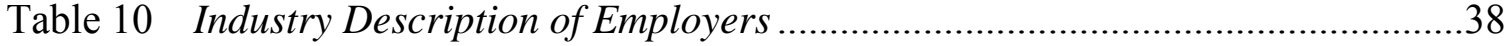

Table 11 Majors Employers Have Hired or Would Consider ......................................40

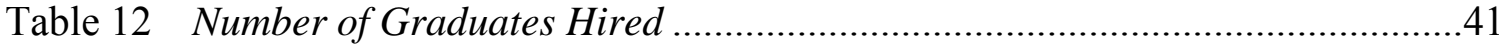

Table 13 Preparation Level of Davis College Graduates for Entry

Level Employment 


\section{CHAPTER I}

Introduction

The main objective of an institution of higher education at the undergraduate level is to prepare students for entry level employment or professional schools. "West Virginia University's primary mission is to provide high-quality programs of instruction at the undergraduate, graduate, and professional levels ..." (West Virginia University, 2003, p. 11). In addition to its primary mission statement as a land grant institution, West Virginia University has specific goals for each level of education provided in its degree programs. The goals of undergraduate education for West Virginia University Baccalaureate degrees state:

West Virginia University is committed to providing high-quality education to all students... This foundation for lifelong learning should provide the knowledge and skills necessary to deal with social, cultural, and technological change. Students should develop critical thinking and problem-solving skills sufficient for life in contemporary society. These skills include the ability to read critically, listen critically, ask appropriate questions, gather relevant information, and apply critical analysis to reach logical conclusions. Central to these skills are mathematical literacy and proficiency in oral and written communications. Students should attain proficiency in their major fields. This proficiency should enable them to be competitive in the job market or in admission to graduate or professional schools. (West Virginia University, 2003, p. 26) 
Over the years, many of the courses taught at the university level have moved away from the basic core of communication and delivery skills to a more diverse knowledge and technical core curriculum.

For more than a decade, employers have expressed a concern for the lack of graduates sufficiently trained to meet the challenges of a highperformance workplace. It has been proposed that the curricula of agriculture were out of date and should be changed. (Kunke, Maw, \& Skaggs, 1996, p. 86)

No matter what technical knowledge students learn while earning their bachelor's degree, without the ability to communicate with potential employers to secure employment, their knowledge and skills may go undiscovered and unused. Gregson and Bettis (1991) found that employers terminate employment, or fail to promote, most employees because of behaviors reflecting an inadequate work value or attitude rather than because of a deficiency in job skills or technical knowledge.

Land grant institutions, in particular, were originally created for research and education purposes in the areas of agriculture and mechanical arts. Specifically, the Morrill Act of 1862 established the land-grant system, with the objective "to teach such branches of learning as are related to agriculture and the mechanical arts" (Morrill LandGrant Act, 1862, p. 503). Subsequent legislation, the Hatch Act of 1877 and the SmithLever Act of 1914, established the Agricultural Experiment Stations and Cooperative Extension Service further defining the roles of the land-grant institution. These acts required the dissemination of research results to the public in reports and bulletins as well 
as developing practical applications of the research knowledge to be taught to citizens not attending colleges or universities.

The basic premise of land-grant institutions would imply a strong emphasis on communication skills to fulfill the objectives and requirements of their missions. Whether it is in the goal of training and development of agriculture teachers and extension agents or in the dissemination of research knowledge through the experiment station or extension programs, communication skills should be one of the major components in the curriculum of land-grant institutions.

"Communication is a big part of agriculture. Whether it is selling your corn to the elevator or a manufacturer selling corn flakes to a consumer, communication is the key. The farmer or rancher of today must be a savvy businessman to make it" (Hasenauer, 2001, p. 1).

Such statements, in addition to the goals, make it apparent that career enrichment skills such as communications must be included in the curriculums of land-grant institutions.

\section{Problem Statement}

How a land-grant institution trains and educates its students for career success will likely determine the future effectiveness and prosperity of its programs. The agriculture industry, particularly in the area of agribusiness, has expanded and diversified significantly over the last few decades. Agriculture is no longer a production based industry. The diversity and change in the agribusiness world has expanded job opportunities for students of agriculture. The question that needs to be answered is whether land-grant institutions are educating and training its students to be competitive in the vast agribusiness job force. 
With the expansion and diversification in the agribusiness industry, the skills needed by graduates of land-grant institutions are expanding and diversifying as well. The effectiveness of the programs in providing students with the required skills to secure employment will likely determine the success of the graduates of land-grant institutions and the future success of the institutions themselves. What are the skills required for graduates to secure employment in the agribusiness industry? Purpose of the Study

The purpose of this study was to determine the skills needed by students graduating from land-grant institutions to be employed in the agribusiness industry. Additionally, this study was designed to determine the skills that will increase the chances of graduates competing for employment in the agribusiness industry. What are the skills that will improve the opportunities for graduates to secure employment? What are employers in agribusiness and government looking for when they interview and hire students of agriculture? Learning what these companies and government entities are seeking in employees is vitally important to the future competitiveness of graduates of West Virginia University. This study will provide an insight into the skills Davis College of Agriculture, Forestry and Consumer Sciences graduates need to obtain jobs.

\section{Objectives of the Study}

The specific objectives for this study were:

1. To identify items of importance to employers for successful interviewing.

2. To determine the personality traits and life experiences that are important for success on the job. 
3. To identify the communication skills, business skills and business abilities possessed by graduates of the Davis College as perceived by recruiters and employers of Davis College graduates.

4. To determine what communication skills, business skills, and business abilities employers deem important for entry level employment.

5. To identify the demographics of employers that recruit Davis College graduates based on the industry type, the majors they have hired, the majors these employers would consider hiring, and the number of graduates hired.

\section{Limitations of the Study}

This study was limited to the perceptions of the agribusiness firms who were in attendance at the Davis College of Agriculture, Forestry and Consumer Sciences Fall Career Fair in November 2004 and may not represent all types of firms in type and size. Additional firms contacted will be limited to the contacts available from the past attendees of the Career Fair or businesses who have expressed an interest in the Career Fair. The contact information for the population was acquired from the Associate Dean's office database and is limited to the accuracy of the contact information. The skills needed for government jobs will be limited to the perceptions of key personnel in the state and federal offices located in West Virginia.

\section{Definitions}

Career Fair - Bi-Annual Career Fair held by the Davis College in Percival Hall in the fall and spring semesters with agribusiness firms attending for the purposes of recruiting, interviewing and screening potential employees graduating from West Virginia University. 
Davis College - West Virginia University Davis College of Agriculture, Forestry and Consumer Sciences. 


\section{CHAPTER II}

Review of Literature

\section{Need for Change and Review of Curriculum}

The W.K. Kellogg Foundation (1994) challenged land-grant institutions to assess whether undergraduate programs are still relevant to employers. There is little debate about the technical skills and knowledge being taught to college graduates. The question lies in the preparedness of college graduates in the non-technical abilities or employability skills. Wentling (1987) observed, "Employers have no quarrel with the skills performance of today's graduates, but they do have serious reservations when it comes to their non-technical abilities" (p. 315). The curricula provided at institutions of higher education must continually evaluate and examine their effectiveness at preparing college graduates for the work force. Garton, Robinson and Campbell (2004) stated, "One certainty is that continuous efforts must be made to revise and update curriculum to ensure it is meeting student needs in the ever-changing workforce" (p. 115). If agricultural programs are to survive, the agriculture curricula must be dynamic and able to adjust to new situations and environments that help improve the on-the-job effectiveness of future graduates (Coorts, 1987; Slocombe \& Baugher, 1988; Scanlon, Bruening, \& Condero 1996).

Assessing Employers Needs and Desires

Gall, Borg, and Gall (1996) define a need as a discrepancy between an existing set of conditions and a desired set of conditions. Numerous studies over the last fifteen years have investigated and discovered various needs desired by employers. Andelt, Barrett, and Bosshamer (1997), and Singh, Ekanem, Tegegne, and Muhammed (2000), found that 
the employees with leadership abilities, especially in the areas of problem solving and team work were found desirable by employers. This added to Klein's (1990) finding that the ability to be a team player was important for employees to possess. Klein identified other skills including the ability to read and understand specific technical information, to listen and carry out instructions, use general business computer software, interpret and use math and statistical methods, have high ethical values, a positive work ethic, and being self motivated. Long, Straquadine, and Campbell (1992) found that employers value knowledge and skills in the computer sciences and oral and written communication. Findings from Blezek and Dillon (1991) indicate that graduates need honesty, integrity and fairness, interest in learning, positive work ethics, willingness to work, reading comprehension, written communication, and math and computation skills. Radhakrishna and Bruening (1994) found that employees and students value interpersonal, business, and communication skills. Customer relations and communication skills were also stated by Spotanski and Foster (1989) as additional skills needed by graduates. Additional requirements of practical work experience and leadership preparation are needed for today's graduates to succeed in the workplace (Merritt \& Hamm, 1994, Brown \& Fritz, 1993). A great deal of research has been conducted on the subject of employer needs over the past years making a case for continuing the work.

\section{Defining Employability Skills}

Business and industry representatives express considerable dissatisfaction with the general level of preparedness of prospective entry-level employees, more than half our young people leave school without the 
knowledge or foundation required to find and hold a good job. (SCANS 1991, p. xv)

Cotton (1993) stated that employers' dissatisfaction with young job applicants is not primarily due to inadequate technical knowledge but in their non-technical abilities. Another name for these non-technical abilities is employability skills. "Employability skills are the attributes of employees, other than technical competence, that make them an asset to the employer" (Buck \& Barrick, 1987, p. 29).

We must remember that employment and employability are not the same thing. Being employed means having a job. For a youth or adult who is not adequately prepared, having a job is likely to be a temporary condition. Being employable means possessing qualities needed to maintain employment and progress in the workplace. (Bhaerman \& Spill, 1998, pp. 42-43)

Cotton (1993) summarized thirty-four research documents to define and place employability skills into three categories of basic skills which include reading and basic arithmetic; higher-order thinking skills which include problem solving and decision making; and affective skills and traits which includes dependability, a positive attitude and cooperativeness. Employability skills are specific to different industries and workplaces.

Need for Industry Input

Motivated to improve the academic and technical skills of the future work force, businesses and schools have joined in partnerships of various sizes and types to achieve their common and separate goals (Lankard, 1995). Higher education has been criticized 
regarding the absence of industry input in the decision making process (Long et al., 1992). "This input is increasingly important due to technological advances. Such a partnership could be used to determine if changes are needed in the curriculum and extracurricular activities" (Graham, 2001, p. 270).

Need assessment is the most important element in the instructional design process. The more that is known about competencies needed in agriculture careers and is incorporated into curriculum development, the more employable agriculture graduates will be in the marketplace. Additionally, the input from employers would provide a benchmark against which future students would be compared and serve as an assessment indicator. (Dick \& Carey, 1996, pp. 67-68)

The research has shown a need for industry input to continue for the evaluation of courses and curricula provided to students and graduates of agriculture.

The ongoing change in society and industry provides a basis to further the investigation into the needs of employers and the skills needed for graduates to be successful in the work force. The input from employers must be obtained and incorporated into the process of curriculum review. The discovery and reporting of employers' needs and industry input into the curriculum and preparedness of graduates is essential to the effectiveness of graduate preparation. This input will provide the data for determining the level of preparation that college graduates are achieving. 


\section{CHAPTER III}

\section{Methodology}

\section{Purpose of the Study}

The purpose of this study was to determine the skills that are needed for students graduating from land-grant institutions to be employed in the agribusiness industry. What are the skills that will improve the opportunities for graduates to secure employment? What are employers in agribusiness and government looking for when they interview and hire students of agriculture? Learning what these companies and government entities are seeking in employees is vitally important to the future competitiveness of graduates of West Virginia University. This study will provide an insight into the skills graduates need to obtain jobs.

\section{Objectives of the Study}

The specific objectives for this study were:

1. To identify items of importance to employers for successful interviewing.

2. To determine the personality traits and life experiences that are important for success on the job.

3. To identify the communication skills, business skills and business abilities possessed by graduates of the Davis College as perceived by recruiters and employers of Davis College graduates.

4. To determine what communication skills, business skills, and business abilities employers deem important for entry level employment. 
5. To identify the demographics of employers that recruit Davis College graduates based on the industry type, the majors they have hired, the majors these employers would consider hiring, and the number of graduates hired.

\section{Research Design}

The research method employed to collect data from the target population was descriptive survey. "Descriptive research is research that asks questions about the nature, incidence, or distribution of variables; it involves describing but not manipulating variables" (Ary, Jacobs, \& Rzavieh, 2002, p. 558). The strengths of descriptive research are that it is possible to collect a wide scope of information from a large population, it deals with the real situation, and it may identify more specific problems. Descriptive research has weaknesses in that it is more extensive than intensive, frequently lacks external validity, and measurement error can be a problem, (Ary, Jacobs \& Rzavieh, 2002, p. XXX). This study was conducted to identify the skills, courses, and attributes that employers desire when interviewing and hiring new employees. It was also conducted to identify the skills which will provide a greater chance of success on the job for college graduates of the Davis College of Agriculture, Forestry and Consumer Sciences at West Virginia University.

\section{Population}

The target population of this study was firms who recruit or hire Davis College graduates. The accessible population of this study was all firms $(\mathrm{N}=211)$ which have attended or expressed interest in the Davis College of Agriculture, Forestry and Consumer Sciences Annual Career Fairs over the last ten years. The population consisted of firms from West Virginia, Maryland, Pennsylvania, Ohio, Virginia, Washington, DC, 
North Carolina, Connecticut, Delaware, Georgia, New York, New Jersey, Kansas, Wisconsin, and California.

\section{Instrumentation}

The survey instrument (see Appendix C) was developed using similar questionnaires from other studies used at Land Grant Institutions (Graham, 2001, and Garton, 2004) and interviews with 14 recruiters at the 2004 Fall Career Fair at the Davis College. Interviews were done with 14 participants of the career fair asking questions (see Appendix A) pertaining to the skills employers look for in applicants and the positive and negative experiences these recruiters have had in hiring college graduates. The responses from the interviews and an adaptation of similar surveys were combined to form the questionnaire for this study.

Sampling and selection errors were controlled by using the entire population for the research. Frame errors were avoided by cross referencing all respondent addresses to eliminate duplicate mailings. Measurement errors were controlled by establishing a valid and reliable instrument. A panel of experts consisting of Davis College faculty established content and face validity. Requirements of the Human Subjects Review Board of West Virginia University were met. Internal instrument reliability was determined from an analysis of data from the accessible population using Cronbach's Alpha. An alpha coefficient rating 0.80 or better by analysis of Cronbach's Alpha shows an exemplary internal consistency estimate of instrument reliability (Robinson, Shaver, \& Wrightsman, 1991). Cronbach's Alpha for the instrument was 0.95 proving an exemplary reliability. An independent $t$-test was performed to analyze responses from 
early and late respondents. No significant differences were found $(\alpha \leq 0.05)$; therefore generalizations were made to the target population.

The questionnaire consisted of five sections. The first section of the survey involved rating items which impact successful interviewing including letters, résumés, and the actual interview. The rating scale for the importance of these items was: 0 - not applicable, 1- not important, 2- somewhat important, 3-important, and 4- very important.

The second section gathered information on items that employers preferred graduates have prior to extending an invitation for a personal interview. The rating scale for level of preference on these items was: 1- reject, 2- accept, and 3- prefer.

Section three consisted of questions concerning personality traits and life experiences which may affect success of new employees in the job place. The items were rated on level of importance based on the following scale: 0 - not applicable, 1 - not important, 2- somewhat important, 3-important, and 4- very important.

The fourth section rated communication skills, business skills, and business abilities for entry level jobs. Respondents were asked to rate graduates on their level of preparation on these items and to rate these items based on their importance to graduates for entry level employment. The preparation of graduates was rated with the following scale: 0- not applicable, 1- not prepared, 2- somewhat prepared, 3-prepared, and 4- very well prepared. The rating scale for the importance of these skills was: 1- not important, 2- somewhat important, 3-important, and 4-very important.

The final section requested demographic information on the respondents consisting of industry type, the majors of graduates the firm has hired and would consider hiring, the number of Davis College graduates the firm has hired in the last five years, 
and general open ended comments on beneficial courses for graduates and additional comments.

\section{Data Collection}

Dillman's (2004) total design method was followed for the data collection process. The researcher made two attempts at gathering data from the target population. The complete questionnaire package consisted of a cover letter (see Appendix B), questionnaire (see Appendix C), and self-addressed business reply envelope. After a two-week response deadline, the second attempt consisted of a complete package including a follow-up letter (see Appendix D), questionnaire, and self-addressed business reply envelope.

Analysis of Data

Each member of the population was assigned a numerical code prior to the initial mailing. This code enabled the researcher to document each survey received and was destroyed to protect the anonymity of the survey participant.

The collected data were analyzed using the Statistical Package for the Social Sciences (SPSS). An Excel spreadsheet was used for data entry. Each variable in the instrument was assigned a numerical value. Open-ended question responses were documented in full text format. Descriptive analyses including frequencies, percentages, and means were used to evaluate numerical data to allow for conversion into narrative form.

\section{Use of Findings}

The findings of this study will be utilized to determine if the current curricula for undergraduates is preparing them for careers. The results will determine if additional 
courses are needed to prepare graduates for obtaining employment and for success in job growth and development. The findings will be provided to the Davis College administration and divisions to make them aware of the perceived preparedness of graduates in the college. The results will also contribute to the body of knowledge on the continuing changes facing land grant institutions and their curricula. 


\section{CHAPTER IV}

\section{Findings}

\section{Purpose of the Study}

The purpose of this study was to determine the non-technical skills needed by students graduating from land-grant institutions to be employed in the agribusiness industry. Additionally, this study was designed to determine the skills that will increase the chances of graduates competing for employment in the agribusiness industry. This study looked at the level of preparation of graduates in a variety of skills and abilities to determine whether Davis College graduates are "career ready." This study was limited to the perceptions of firms who have recruited or hired graduates of the Davis College of Agriculture, Forestry and Consumer Sciences in the last five years.

\section{Objectives of the Study}

Specific objectives for this study were:

1. To identify items of importance to employers for successful interviewing.

2. To determine the personality traits and life experiences that are important for success on the job.

3. To identify the communication skills, business skills and business abilities possessed by graduates of the Davis College as perceived by recruiters and employers of Davis College graduates.

4. To determine what communication skills, business skills, and business abilities employers deem important for entry level employment.

5. To identify the demographics of employers that recruit Davis College graduates based on the industry type, the majors they have hired, the majors these employers would consider hiring, and the number of graduates hired. 
Analysis of Returned Surveys

The target population for this study was firms who recruit or hire Davis College of Agriculture, Forestry and Consumer Sciences graduates. The accessible population consisted of 211 businesses, educational institutions, and government agencies that have recruited or hired graduates of the Davis College of Agriculture, Forestry and Consumer Sciences within the past five years. The population consisted of firms from West Virginia, Maryland, Pennsylvania, Ohio, Virginia, Washington, DC, North Carolina, Connecticut, Delaware, Georgia, New York, New Jersey, Kansas, Wisconsin, and California. Ninety-eight (46\%) questionnaires were returned. Some of Dillman's principles were employed in collecting data. Each attempt included a cover letter, an instrument, and a postage paid business reply return envelope. An initial cover letter (see Appendix B) explained the purpose of this study and instructed respondents about the questionnaire. The questionnaire (see Appendix C) was sent with each mailing and data collected via responses from the study population. A response rate of $32 \%(N=70)$ occurred from the first collection attempt. A follow-up cover letter (see Appendix D) in the same format along with the instrument and a postage paid business reply return envelope was sent to the 141 respondents who did not submit their initial survey prior to the collection deadline. A response rate of $20 \%(N=28)$ occurred during the second and final collection attempt. The total response rate for this study was $46 \%(N=98)$.

Data were entered into an Excel spreadsheet. Data were analyzed using the Statistical Package for the Social Sciences (SPSS). Open-ended comments and questions 
responses were recorded in full. Descriptive analyses including frequencies, percentages, and means were used to evaluate numerical data.

An independent $t$-test was used to compare early and late respondents'

perceptions of the skills needed by graduates to be successful. No significant differences were distinguished when comparing early and late respondents in this study; therefore, generalizations were made to the target population.

Items of Importance for Successful Interviewing

The respondents' perceptions of items which impact successful interviewing were analyzed by frequency and mean and ranked by mean (see Table 1). Responses were averaged and the mean of each item was scaled and reported within a range to determine the level of importance of the items. The ranges for level of importance on items for successful interviewing were very important $(M=3.5-4.0)$; important $(M=2.5-3.49)$; somewhat important $(M=1.5-2.49)$; and not important $(M=1.0-1.49)$. Responses of not applicable were excluded from the calculations of mean for level of importance. The responses for items of importance to successful interviewing were separated into three sub-categories: letters, résumé, and interview.

Letters. Application letters $(M=3.10, n=71,74.7 \%)$ and follow-up letters $(M=2.60, n=51,54.8 \%)$ were both important to successful interviewing.

Résumé. Items of content in the résumé were rated on level of importance to successful interviewing. One item, education $(M=3.65, n=65,67.7 \%)$ was very important to the résumé. Work experience $(M=3.41, n=32,33.3 \%)$, courseworkspecialization $(M=3.25, n=47,49.5 \%)$, personal experience $(M=3.10, n=31,32.3 \%)$, job objective $(M=3.01, n=41,42.7 \%)$, internships $(M=2.86, n=38,39.6 \%)$, dates of prior 
employment $(M=2.69, n=40,41.7 \%)$, and grade point average $(M=2.67, n=36,37.5 \%)$ were all important items based on means to be included in the résumé. Hobbies and interests $(M=2.08, n=35,36.5 \%)$ was the only item ranked somewhat important and none of the items based on means were deemed not important.

Interview. The items that were very important $(M=3.5-4.0)$ to success during the interview based on average were; eye contact $(M=3.58, n=60,62.5 \%)$; appearance $(M=3.50, n=50,52.1 \%)$; and thorough complete answers $(M=3.50, n=54,56.3 \%)$. The remaining six items had a mean score within 2.5-3.49 and were important to successful interviewing. These were: current-revised résumé $(M=3.47, n=32,33.3 \%)$, professional attire $(M=3.32, n=51,53.1 \%)$, questions for interviewer $(M=3.27, n=38,39.6 \%)$, assertiveness ( $M=3.14, n=57,59.4 \%)$, knowledge of company $(M=2.99, n=43,44.8 \%)$, and firm handshake $(M=2.92, n=43,44.8 \%)$. 
Table 1

Items of Importance for Successful Interviewing

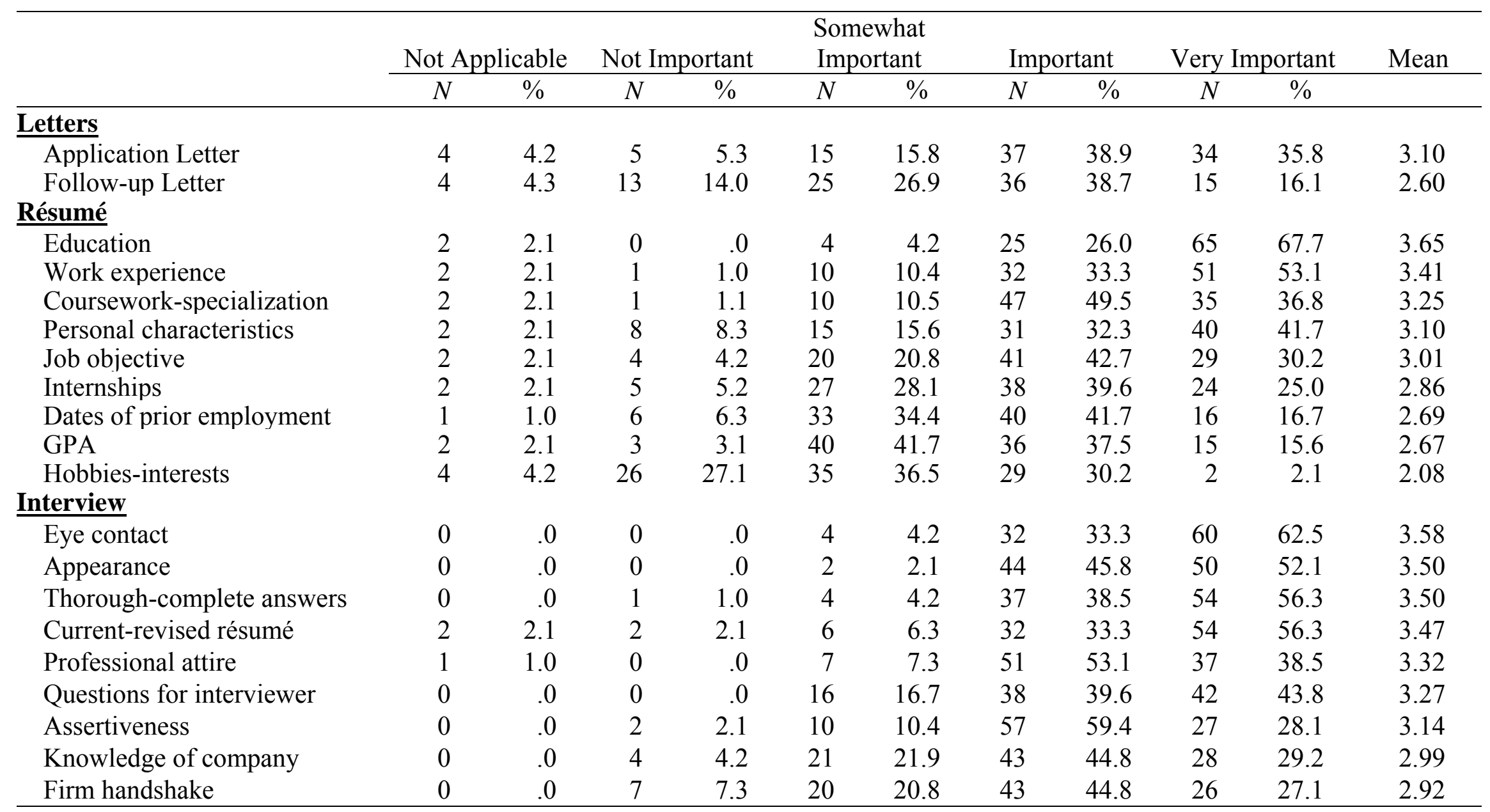

Rating scale: 0-Not Applicable, 1-Not Important, 2-Somewhat Important, 3-Important, 4-Very Important 


\section{Items of Preference for Initial Consideration for an Interview}

Respondents were asked to rate items used for initial consideration or review of qualifications before extending a personal interview on level of preference. The rating scale provided was; 1-reject, 2-accept, and 3-prefer. The responses were placed into subcategories of résumé length, references, and paper and font. Fifty-five (59.8\%) of the respondents preferred a one-page résumé and the remaining $40.2 \%$ ( $N=37)$ would accept a one page résumé. No responses indicated a rejection of a one page résumé. When rating résumés two pages in length, 25 (26.9\%) of the respondents preferred them, 66 (71.0\%) would accept them, and two (2.2\%) of the respondents would reject. One (1.1\%) respondent preferred résumés more than two pages in length, 65 (70.7\%) respondents would accept, and 26 (28.3\%) would reject.

Sixty-two (66.7\%) of the respondents preferred references to be included with the résumé, while 29 (31.2\%) would accept references included and two (2.2\%) would reject individuals if they included references. In response to the number of references preferred by respondents, 78 (85.7\%) preferred or accepted fewer than three references while 13 $(14.3 \%)$ rejected résumés with fewer than three references. On the other hand, 90 (97.8\%) of the respondents preferred or accepted three or more references, while only two $(2.2 \%)$ would reject résumés with three or more references.

In the sub-category of paper and font, 25 (26.9\%) of respondents preferred fine quality paper, 68 (73.1\%) would accept it, and no respondents indicated a rejection of fine quality paper. Two (2.2\%) respondents prefer, 77 (83.7\%) accept, and $13(14.1 \%)$ reject résumés on colored paper. On résumés with colored font type, no respondents preferred, $72(78.3 \%)$ would accept, and 21 (21.7\%) would reject (see Table 2). 
Table 2

Items of Preference for Initial Consideration for an Interview

\begin{tabular}{|c|c|c|c|c|c|c|}
\hline & \multicolumn{2}{|c|}{ Reject } & \multicolumn{2}{|c|}{ Accept } & \multicolumn{2}{|c|}{ Prefer } \\
\hline & $N$ & $\%$ & $N$ & $\%$ & $N$ & $\%$ \\
\hline \multicolumn{7}{|l|}{ Résumé length } \\
\hline 1 page résumé & 0 & .0 & 37 & 40.2 & 55 & 59.8 \\
\hline 2 page résumé & 2 & 2.2 & 66 & 71.0 & 25 & 26.9 \\
\hline More than 2 page résumé & 26 & 28.3 & 65 & 70.7 & 1 & 1.1 \\
\hline \multicolumn{7}{|l|}{ References } \\
\hline References included & 2 & 2.2 & 29 & 31.2 & 62 & 66.7 \\
\hline Fewer than 3 references & 13 & 14.3 & 72 & 79.1 & 6 & 6.6 \\
\hline 3 or more references & 2 & 2.2 & 48 & 52.2 & 42 & 45.7 \\
\hline \multicolumn{7}{|l|}{ Paper and font } \\
\hline Fine quality paper & 0 & .0 & 68 & 73.1 & 25 & 26.9 \\
\hline Colored paper & 13 & 14.1 & 77 & 83.7 & 2 & 2.2 \\
\hline Colored font type & 20 & 21.7 & 72 & 78.3 & 0 & .0 \\
\hline
\end{tabular}

Personality Skills and Traits Important to Success

The responses to personality skills and traits that are important to success in the job place were analyzed by frequency and mean and ranked by mean (see Table 3 ).

Responses were averaged and the mean of each item was scaled and reported within a range to determine the level of importance of the items. The ranges for level of importance on personality skills and traits were very important $(M=3.5-4.0)$; important $(M=2.5-3.49)$; somewhat important $(M=1.5-2.49)$; and not important $(M=1.0-1.49)$.

Responses of not applicable were not found.

Eleven personality skills and traits were reported as very important $(M=3.5-4.0)$, with trustworthy $(M=3.91, n=87,90.6 \%)$ the highest ranked followed by; honest 
$(M=3.88, n=84,87.5 \%)$; good work ethic $(M=3.84, n=81,84.4 \%)$; motivated $(M=3.81$, $n=78,81.3 \%)$; dependable $(M=3.78, n=75,78.1 \%)$; team player $(M=3.77, n=76$, 79.2\%); hardworking ( $M=3.72, n=70,72.9 \%)$; dedicated $(M=3.68, n=68,70.8 \%)$; shows initiative ( $M=3.66, n=66,68.8 \%)$; organized ( $M=3.52, n=54,56.3 \%)$; and works independently $(M=3.51, n=55,57.3 \%)$. Goal oriented $(M=3.42, n=40,41.7 \%)$ and exudes confidence $(M=3.11, n=46,47.9 \%)$ were rated as important $(M=2.5-3.49)$ traits for success on the job. Based on rankings of mean, no respondents rated any of the skills and traits as somewhat important $(M=1.5-2.49)$ or not important $(M=1.0-1.49)$.

Table 3

Personality Skills and Traits Important to Success

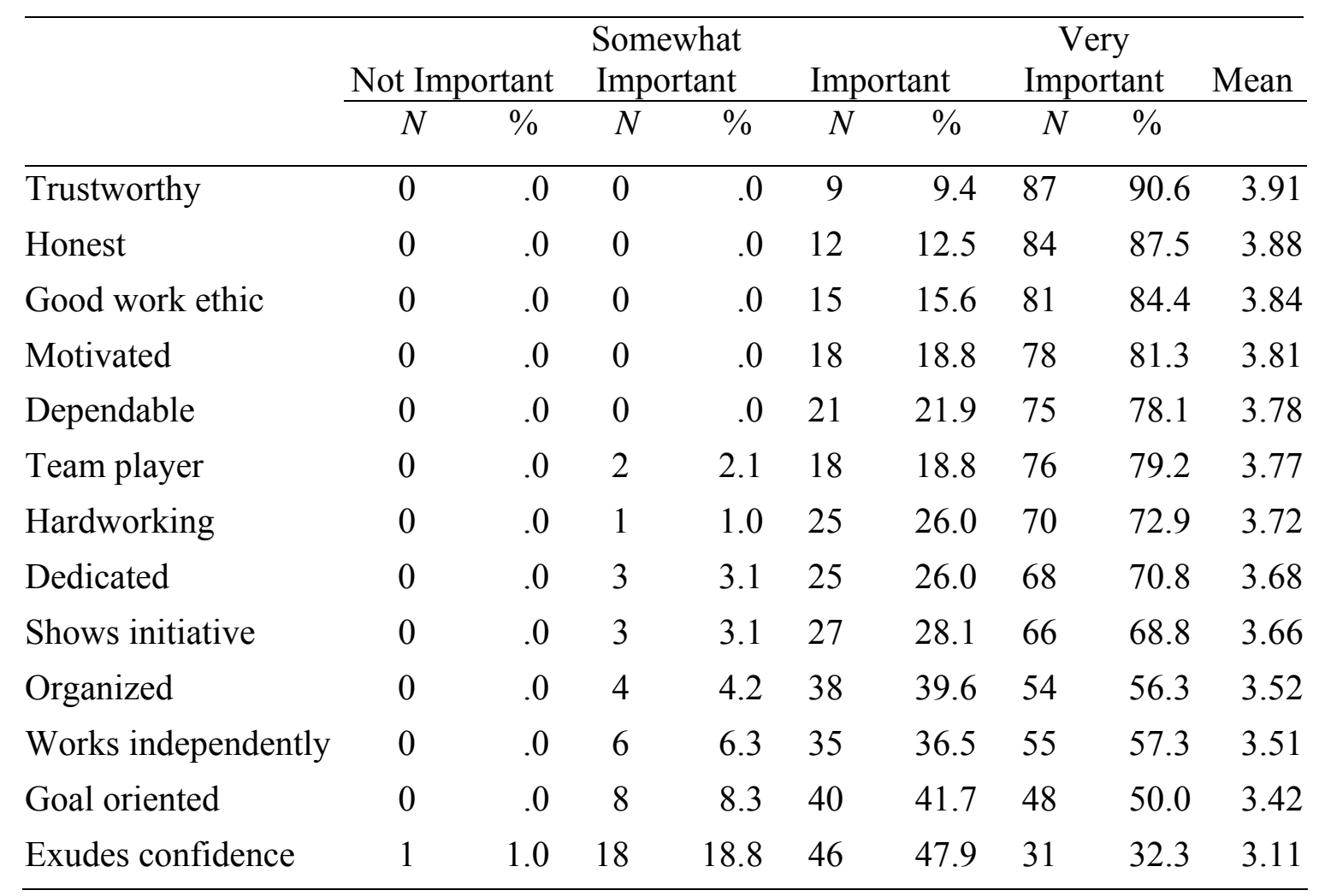

Rating scale: 1-Not Important, 2-Somewhat Important, 3-Important, 4-Very Important 


\section{Importance of Experiences to Success of New Employees}

Respondents were asked to rate the level of importance of experiences as to their impact on the success of new employees in their organizations. The responses were analyzed by frequency and mean and ranked by mean. Responses were averaged and the mean of each item was scaled and reported within a range to determine the level of importance of the items. The ranges for level of importance on personality skills and traits were very important $(M=3.5-4.0)$; important $(M=2.5-3.49)$; somewhat important $(M=1.5-2.49)$; and not important $(M=1.0-1.49)$. Responses of not applicable were excluded from the calculations of mean for level of importance (see Table 3).

Based on the means, all responses fell into the important $(M=2.5-3.49)$ or somewhat important $(M=1.5-2.49)$ categories. No respondents rated any of the experiences for success as very important $(M=3.5-4.0)$ or not important $(M=1.0-1.49)$. In order of ranking, the following experiences based on mean were found to be important to the success of new employees on the job: career-related employment $(M=3.31, n=29$, $30.2 \%)$; hands-on experiences $(M=3.20, n=49,51.6 \%)$; practical experiences $(M=3.17$, $n=50,52.1 \%)$; career-related internships $(M=3.05, n=35,36.5 \%)$; general work experience $(M=2.92, n=48,50.0 \%)$; life experiences $(M=2.85, n=59,61.5 \%)$; and community-volunteer programs $(M=2.53, n=39,40.6 \%)$.

The remaining seven experiences were reported based on mean as somewhat important $(M=1.5-2.49)$ to the success of new employees on the job. Participation in honors programs $(M=2.03, n=42,43.8 \%)$, active student club member $(M=1.97, n=47$, 49.0\%), officer of student club ( $M=1.93, n=40,41.7 \%)$, labs $(M=1.92, n=44,45.8 \%)$, field trips $(M=1.84, n=39,40.6 \%)$ and agricultural mechanics $(M=1.84, n=32,33.3 \%)$, 
and international experiences $(M=1.59, n=31,32.3 \%)$ were experiences rated as somewhat important.

Preparation of Graduates in Communication Skills

The respondents' rated the level of preparation of graduates on twelve separate communication skills (see Table 5). Responses were averaged and the mean of each item was scaled and reported within a range to determine the level of preparation of graduates in each skill. The ranges for level of preparation of communication skills were very well prepared $(M=3.5-4.0)$; prepared $(M=2.5-3.49)$; somewhat prepared $(M=1.5-2.49)$; and not prepared $(M=1.0-1.49)$. Responses of not applicable were excluded from the calculations of mean for level of preparation. Based on mean respondents did not rate any of the communication skills of graduates as very well prepared $(M=3.5-4.0)$ or not prepared $(M=1.0-1.49)$. Graduates were prepared $(M=2.5-3.49)$ for: following instructions $(M=2.71, n=47,49.5 \%)$; one-on-one communications $(M=2.70, n=53,55.8 \%)$; contributing in small groups $(M=2.67, n=53,55.8 \%)$; oral communication $(M=2.61$, $n=41,43.2 \%)$; expressing thoughts and ideas $(M=2.57, n=47,49.5 \%)$; effective use of verbal skills $(M=2.53, n=39,41.1 \%)$; and listening $(M=2.51, n=41,43.6 \%)$.

There were five communication skills based on mean that the respondents rated graduates as somewhat prepared $(M=1.5-2.49)$. Using effective nonverbal skills $(M=2.37, n=52,54.7 \%)$, presentation skills $(M=2.37, n=41,43.2 \%)$, written skills $(M=2.36, n=46,48.4 \%)$, giving instructions $(M=2.21, n=44,46.3 \%)$, and public speaking $(M=2.11, n=43,45.3 \%)$ were the communication skills graduates were least prepared for with public speaking being the lowest. 
Table 4

Importance of Experiences to Success of New Employees

\begin{tabular}{|c|c|c|c|c|c|c|c|c|c|c|c|}
\hline & \multicolumn{2}{|c|}{ Not Applicable } & \multicolumn{2}{|c|}{ Not Important } & \multicolumn{2}{|c|}{$\begin{array}{l}\text { Somewhat } \\
\text { Important }\end{array}$} & \multicolumn{2}{|c|}{ Important } & \multicolumn{2}{|c|}{ Very Important } & \multirow[t]{2}{*}{ Mean } \\
\hline & $N$ & $\%$ & $N$ & $\%$ & $N$ & $\%$ & $N$ & $\%$ & $N$ & $\%$ & \\
\hline Career-related employment & 0 & .0 & 1 & 1.0 & 17 & 17.7 & 29 & 30.2 & 49 & 51.0 & 3.31 \\
\hline Hands-on experiences & 0 & .0 & 1 & 1.1 & 12 & 12.6 & 49 & 51.6 & 33 & 34.7 & 3.20 \\
\hline Practical experiences & 1 & 1.0 & 1 & 1.0 & 13 & 13.5 & 50 & 52.1 & 31 & 32.3 & 3.17 \\
\hline Career-related internships & 2 & 2.1 & 2 & 2.1 & 24 & 25.0 & 35 & 36.5 & 33 & 34.4 & 3.05 \\
\hline General work experience & 0 & .0 & 0 & .0 & 28 & 29.2 & 48 & 50.0 & 20 & 20.8 & 2.92 \\
\hline Life experiences & 1 & 1.0 & 4 & 4.2 & 19 & 19.8 & 59 & 61.5 & 13 & 13.5 & 2.85 \\
\hline Community-volunteer programs & 0 & .0 & 10 & 10.4 & 36 & 37.5 & 39 & 40.6 & 11 & 11.5 & 2.53 \\
\hline Participation in Honors Programs & 4 & 4.2 & 24 & 25.0 & 42 & 43.8 & 25 & 26.0 & 1 & 1.0 & 2.03 \\
\hline Active student club member & 3 & 3.1 & 27 & 28.1 & 47 & 49.0 & 14 & 14.6 & 5 & 5.2 & 1.97 \\
\hline Officer of student club & 4 & 4.2 & 31 & 32.3 & 40 & 41.7 & 17 & 17.7 & 4 & 4.2 & 1.93 \\
\hline Labs & 9 & 9.4 & 26 & 27.1 & 44 & 45.8 & 15 & 15.6 & 2 & 2.1 & 1.92 \\
\hline Field trips & 5 & 5.2 & 35 & 36.5 & 39 & 40.6 & 14 & 14.6 & 3 & 3.1 & 1.84 \\
\hline Agricultural mechanics & 27 & 28.1 & 26 & 27.1 & 32 & 33.3 & 7 & 7.3 & 4 & 4.2 & 1.84 \\
\hline International experiences & 4 & 4.2 & 51 & 53.1 & 31 & 32.3 & 7 & 7.3 & 3 & 3.1 & 1.59 \\
\hline
\end{tabular}

Rating scale: 0-Not Applicable, 1-Not Important, 2-Somewhat Important, 3-Important, 4-Very Important 
Table 5

Preparation of Graduates in Communication Skills

\begin{tabular}{|c|c|c|c|c|c|c|c|c|c|c|c|}
\hline & \multicolumn{2}{|c|}{ Not Applicable } & \multicolumn{2}{|c|}{ Not Prepared } & \multicolumn{2}{|c|}{$\begin{array}{l}\text { Somewhat } \\
\text { Prepared }\end{array}$} & \multicolumn{2}{|c|}{ Prepared } & \multicolumn{2}{|c|}{$\begin{array}{l}\text { Very Well } \\
\text { Prepared }\end{array}$} & \multirow{2}{*}{ Mean } \\
\hline & $N$ & $\%$ & $N$ & $\%$ & $N$ & $\%$ & $N$ & $\%$ & $N$ & $\%$ & \\
\hline Following instructions & 2 & 2.1 & 3 & 3.2 & 32 & 33.7 & 47 & 49.5 & 11 & 11.6 & 2.71 \\
\hline One-on-one communication & 1 & 1.1 & 1 & 1.1 & 33 & 34.7 & 53 & 55.8 & 7 & 7.4 & 2.70 \\
\hline Contribute in small groups & 2 & 2.1 & 5 & 5.3 & 28 & 29.5 & 53 & 55.8 & 7 & 7.4 & 2.67 \\
\hline Oral communication & 1 & 1.1 & 2 & 2.1 & 42 & 44.2 & 41 & 43.2 & 9 & 9.5 & 2.61 \\
\hline Expressing ideas-thoughts & 1 & 1.1 & 1 & 1.1 & 42 & 44.2 & 47 & 49.5 & 4 & 4.2 & 2.57 \\
\hline Effective verbal skills & 1 & 1.1 & 5 & 5.3 & 42 & 44.2 & 39 & 41.1 & 8 & 8.4 & 2.53 \\
\hline Listening & 1 & 1.1 & 8 & 8.5 & 37 & 39.4 & 41 & 43.6 & 7 & 7.4 & 2.51 \\
\hline Effective nonverbal skills & 1 & 1.1 & 6 & 6.3 & 52 & 54.7 & 31 & 32.6 & 5 & 5.3 & 2.37 \\
\hline Presentation skills & 6 & 6.3 & 11 & 11.6 & 41 & 43.2 & 30 & 31.6 & 7 & 7.4 & 2.37 \\
\hline Written skills & 1 & 1.1 & 10 & 10.5 & 46 & 48.4 & 32 & 33.7 & 6 & 6.3 & 2.36 \\
\hline Giving instructions & 6 & 6.3 & 15 & 15.8 & 44 & 46.3 & 26 & 27.4 & 4 & 4.2 & 2.21 \\
\hline Public speaking & 4 & 4.2 & 22 & 23.2 & 43 & 45.3 & 20 & 21.1 & 6 & 6.3 & 2.11 \\
\hline
\end{tabular}

Rating scale: 0-Not Applicable, 1-Not Prepared, 2-Somewhat Prepared, 3-Prepared, 4-Very Well Prepared 


\section{Preparation of Graduates in Business Skills}

The preparation levels of graduates on six business skills were rated by respondents. Responses were averaged and the mean of each item was scaled and reported within a range to determine the level of preparation of graduates in each skill. The ranges for level of preparation of business skills were very well prepared $(M=3.5$ 4.0); prepared $(M=2.5-3.49)$; somewhat prepared $(M=1.5-2.49)$; and not prepared $(M=1.0-1.49)$. Responses of not applicable were excluded from the calculations of mean for level of preparation. As with communication skills, based on means respondents did not rate any of the business skills of graduates as very well prepared $(M=3.5-4.0)$ or not prepared $(M=1.0-1.49)$.

Of the six business skills respondents rated, graduates were prepared in two skill areas and somewhat prepared in four other skill areas. The prepared skills were computer skills $(M=3.18, n=56,60.2 \%)$ and planning and completing projects $(M=2.68, n=45$, 48.4\%). Respondents rated graduates as somewhat prepared in the skills of needs assessment $(M=2.46, n=39,42.4 \%)$, time management $(M=2.44, n=38,40.9 \%)$, decision-making $(M=2.31, n=54,58.1 \%)$, and conflict resolution $(M=1.99, n=49$, $52.7 \%$ ) (see Table 6). 
Table 6

Preparation of Graduates in Business Skills

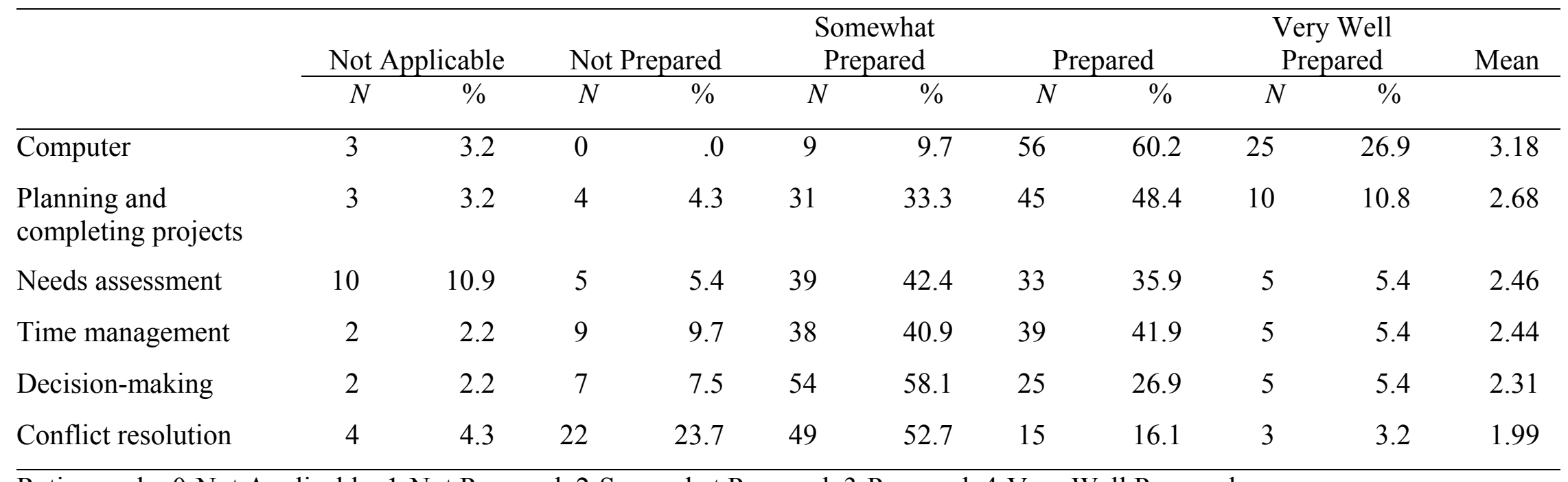

Rating scale: 0-Not Applicable, 1-Not Prepared, 2-Somewhat Prepared, 3-Prepared, 4-Very Well Prepared 


\section{Preparation of Graduates in Business Abilities}

Respondents rated the level of preparation seen in graduates for the following business abilities: professional appearance, professional behavior, leadership, self evaluation, supervision, marketing, and management (see Table 7). Responses were averaged and the mean of each item was scaled and reported within a range to determine the level of preparation of graduates in business abilities. The ranges for level of preparation of business skills were very well prepared $(M=3.5-4.0)$; prepared $(M=2.5$ 3.49); somewhat prepared $(M=1.5-2.49)$; and not prepared $(M=1.0-1.49)$. Responses of not applicable were excluded from the calculations of mean for level of preparation. Once again, based on means, respondents did not perceive graduates' preparation levels for business abilities as very well prepared $(M=3.5-4.0)$ or not prepared $(M=1.0-1.49)$.

Graduates were prepared $(M=2.5-3.49)$ for two of the business abilities and somewhat prepared ( $M=1.5-2.49)$ for five other of the abilities. Professional appearance $(M=2.68, n=44,47.8 \%)$ and professional behavior $(M=2.64, n=41,44.6 \%)$ were rated as prepared by respondents. The preparation levels of graduates for leadership $(M=2.40$, $n=44,47.8 \%)$, self evaluation $(M=2.31, n=48,52.7 \%)$, supervision $(M=2.22, n=44$, $47.8 \%)$, marketing $(M=2.15, n=39,42.9 \%)$ and management $(M=2.13, n=39,42.4 \%)$ were somewhat prepared. 
Table 7

Preparation of Graduates in Business Abilities

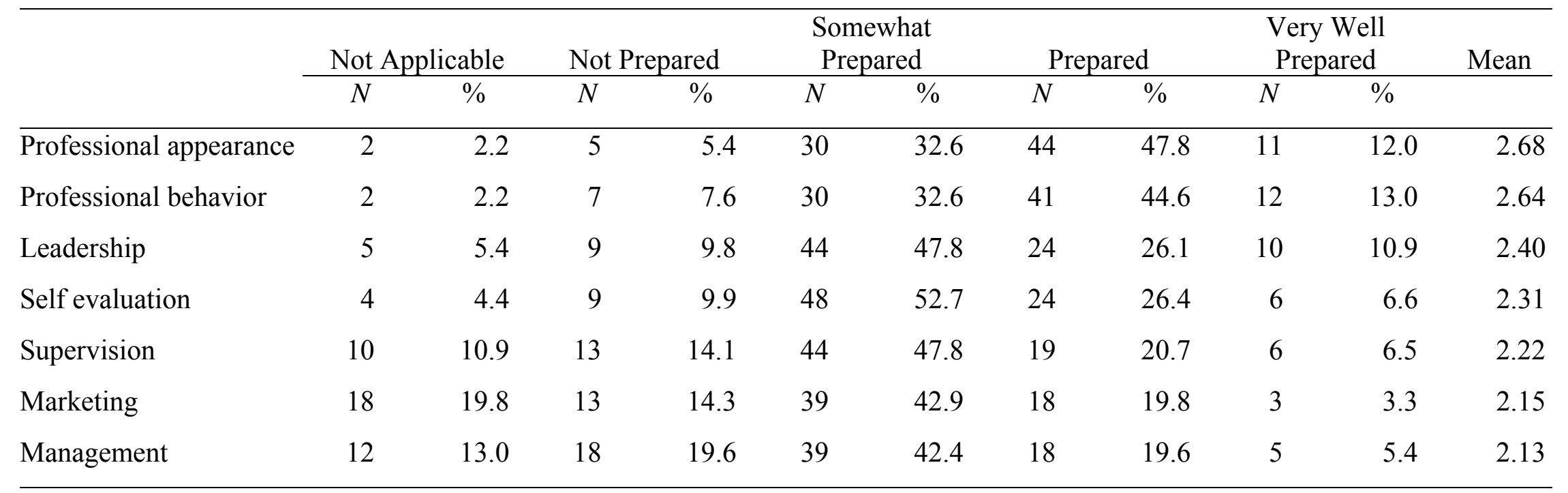

Rating scale: 0-Not Applicable, 1-Not Prepared, 2-Somewhat Prepared, 3-Prepared, 4-Very Well Prepared 


\section{Preparation of Davis College Graduates Compared to College Graduates}

After each of the three sections on preparation levels of graduates in communications skills, business skills, and business abilities, respondents were asked about the preparation of Davis College of Agriculture, Forestry and Consumer Sciences graduates in those skills. The responses of those three questions were compared to the average and means of the answers from the three sections. Responses were averaged and the mean of each item was scaled and reported within a range to determine the level of preparation of graduates in business abilities. The ranges for level of preparation of the three sections were very well prepared ( $M=3.5-4.0)$; prepared $(M=2.5-3.49)$; somewhat prepared ( $M=1.5-2.49)$; and not prepared $(M=1.0-1.49)$. Responses of not applicable were excluded from the calculations of mean for level of preparation (see Table 8).

Graduates of the Davis College were as equally prepared as College graduates in communication skills, business skills and business abilities. No statistically significant differences were found in the average means in preparation levels of Davis College graduates and College graduates. In analyzing communication skills, College graduates were prepared $(M=2.52, n=43,45.7 \%)$ on average of all skills compared to Davis College graduates who were rated as somewhat prepared $(M=2.47, n=42,54.5 \%)$. College graduates were also prepared $(M=2.51, n=43,47.3 \%)$ in business skills, while Davis College graduates were somewhat prepared $(M=2.49, n=33,45.2 \%)$ in these skills. The comparison of responses for business abilities showed that College graduates $(M=2.39, n=51,56.7 \%)$ and Davis College graduates $(M=2.44, n=37,50.7 \%)$ were both somewhat prepared with these abilities with Davis College graduates being slightly more prepared. 
Table 8

Preparation of Davis College Graduates Compared to College graduates



Rating scale: 0-Not Applicable, 1-Not Prepared, 2-Somewhat Prepared, 3-Prepared, 4-Very Well Prepared 


\section{Importance of Skills and Traits to Entry Level Employment}

In addition to preparation level of graduates, respondents rated the 25 skills and traits on level of importance for entry level employees (see Table 9). The skills and traits were placed into the three categories of communication skills, business skills, and business abilities. Responses were averaged and the mean of each item was scaled and reported within a range to determine the level of importance for graduates in the skills and traits. The ranges for level of importance of the three sections were very important $(M=3.5-4.0)$; important ( $M=2.5-3.49)$; somewhat important $(M=1.5-2.49)$; and not important $(M=1.0-1.49)$. Based on averages, none of the skills or traits were rated as not important $(M=1.0-1.49)$.

Respondents indicated that all of the communication skills were either very important ( $M=3.5-4.0)$ or important $(M=2.5-3.49)$ for entry level employees to possess. Ranked by mean the very important communication skills were: effective verbal skills $(M=3.64, n=60,63.8 \%)$; oral communication $(M=3.63, n=60,63.8 \%)$; listening ( $M=3.62, n=59,62.8)$; following instructions $(M=3.61, n=60,63.8 \%)$; and one-on-one communication $(M=3.50, n=51,54.3 \%)$. The remaining seven communication skills were important $(M=2.5-3.49)$ with a range between expressing ideas and thoughts $(M=3.46, n=41,43.6 \%)$ to giving instructions $(M=2.98, n=50,54.9 \%)$.

When rating the six business skills on level of importance, by mean respondents rated two skills very important $(M=3.5-4.0)$ and four skills as important $(M=2.5-3.49)$. Time management $(M=3.63)$ and planning and completing projects $(M=3.61)$ were very important skills for entry level employees. Respondents rated decision-making 
$(M=3.42)$, computer $(M=3.25)$, conflict resolution $(M=3.18)$ and needs assessment $(M=2.85)$ as important skills for graduates to possess.

The rating of importance based on means for business abilities ranged from one very important $(M=3.5-4.0)$, five important $(M=2.5-3.49)$, and one somewhat important $(M=1.5-2.49)$. Professional behavior $(M=3.64, n=62,68.1 \%)$ was rated as very important by respondents. The following abilities were rated important for entry level employees: leadership $(M=3.27, n=49,54.4 \%)$; professional appearance $(M=3.27, n=49$, $53.3 \%)$; self evaluation $(M=2.99, n=49,55.1 \%)$; supervision $(M=2.82, n=39,44.8 \%)$; and management $(M=2.81, n=34,38.6 \%)$. The one business ability rated as somewhat important by mean was marketing $(M=2.40, n=32,37.2 \%)$.

Table 9

Importance of Skills and Traits to Entry Level Employment

\begin{tabular}{|c|c|c|c|c|c|c|c|c|c|}
\hline & \multicolumn{2}{|c|}{$\begin{array}{c}\text { Not } \\
\text { Important }\end{array}$} & \multicolumn{2}{|c|}{$\begin{array}{l}\text { Somewhat } \\
\text { Important }\end{array}$} & \multicolumn{2}{|c|}{ Important } & \multicolumn{2}{|c|}{$\begin{array}{c}\text { Very } \\
\text { Important }\end{array}$} & \multirow[t]{2}{*}{ Mean } \\
\hline & $N$ & $\%$ & $N$ & $\%$ & $N$ & $\%$ & $N$ & $\%$ & \\
\hline \multicolumn{10}{|l|}{ Communication Skills } \\
\hline Effective verbal skills & 0 & .0 & 0 & .0 & 34 & 36.2 & 60 & 63.8 & 3.64 \\
\hline Oral communication & 0 & .0 & 1 & 1.1 & 33 & 35.1 & 60 & 63.8 & 3.63 \\
\hline Listening & 0 & .0 & 1 & 1.1 & 34 & 36.2 & 59 & 62.8 & 3.62 \\
\hline Following instructions & 0 & .0 & 3 & 3.2 & 31 & 33.0 & 60 & 63.8 & 3.61 \\
\hline $\begin{array}{l}\text { One-on-one } \\
\text { communication }\end{array}$ & 0 & .0 & 4 & 4.3 & 39 & 41.5 & 51 & 54.3 & 3.50 \\
\hline Expressing ideas-thoughts & 0 & .0 & 5 & 5.3 & 41 & 43.6 & 48 & 51.1 & 3.46 \\
\hline Written skills & 0 & .0 & 4 & 4.3 & 47 & 50.0 & 43 & 45.7 & 3.41 \\
\hline Effective nonverbal skills & 0 & .0 & 10 & 10.6 & 50 & 53.2 & 34 & 36.2 & 3.26 \\
\hline Contribute in small groups & 0 & .0 & 9 & 9.7 & 52 & 55.9 & 32 & 34.4 & 3.25 \\
\hline Public speaking & 3 & 3.2 & 17 & 18.3 & 39 & 41.9 & 34 & 36.6 & 3.12 \\
\hline Presentation skills & 3 & 3.3 & 20 & 22.0 & 34 & 37.4 & 34 & 37.4 & 3.09 \\
\hline Giving instructions & 1 & 1.1 & 20 & 22.0 & 50 & 54.9 & 20 & 22.0 & 2.98 \\
\hline
\end{tabular}

Rating scale: 1-Not Important, 2-Somewhat Important, 3-Important, 4-Very Important 
Table 9 (continued)

Importance of Skills and Traits to Entry Level Employment

\begin{tabular}{|c|c|c|c|c|c|c|c|c|c|}
\hline & \multicolumn{2}{|c|}{$\begin{array}{c}\text { Not } \\
\text { Important }\end{array}$} & \multicolumn{2}{|c|}{$\begin{array}{l}\text { Somewhat } \\
\text { Important }\end{array}$} & \multicolumn{2}{|c|}{ Important } & \multicolumn{2}{|c|}{$\begin{array}{c}\text { Very } \\
\text { Important }\end{array}$} & \multirow[t]{2}{*}{ Mean } \\
\hline & $N$ & $\%$ & $N$ & $\%$ & $N$ & $\%$ & $N$ & $\%$ & \\
\hline \multicolumn{10}{|l|}{ Business Skills } \\
\hline Time management & 0 & .0 & 1 & 1.1 & 32 & 34.4 & 60 & 64.5 & 3.63 \\
\hline $\begin{array}{l}\text { Planning \& completing } \\
\text { projects }\end{array}$ & 0 & .0 & 1 & 1.1 & 34 & 37.0 & 57 & 62.0 & 3.61 \\
\hline Decision-making & 0 & .0 & 7 & 7.5 & 40 & 43.0 & 46 & 49.5 & 3.42 \\
\hline Computer & 2 & 2.2 & 11 & 11.8 & 42 & 45.2 & 38 & 40.9 & 3.25 \\
\hline Conflict resolution & 3 & 3.2 & 12 & 12.9 & 43 & 46.2 & 35 & 37.6 & 3.18 \\
\hline Needs assessment & 8 & 8.8 & 16 & 17.6 & 49 & 53.8 & 18 & 19.8 & 2.85 \\
\hline \multicolumn{10}{|l|}{ Business Abilities } \\
\hline Professional behavior & 0 & .0 & 4 & 4.4 & 25 & 27.5 & 62 & 68.1 & 3.64 \\
\hline Leadership & 1 & 1.1 & 7 & 7.8 & 49 & 54.4 & 33 & 36.7 & 3.27 \\
\hline Professional appearance & 0 & .0 & 9 & 9.8 & 49 & 53.3 & 34 & 37.0 & 3.27 \\
\hline Self evaluation & 3 & 3.4 & 16 & 18.0 & 49 & 55.1 & 21 & 23.6 & 2.99 \\
\hline Supervision & 6 & 6.9 & 23 & 26.4 & 39 & 44.8 & 19 & 21.8 & 2.82 \\
\hline Management & 9 & 10.2 & 22 & 25.0 & 34 & 38.6 & 23 & 26.1 & 2.81 \\
\hline Marketing & 14 & 16.3 & 32 & 37.2 & 32 & 37.2 & 8 & 9.3 & 2.40 \\
\hline
\end{tabular}

Rating scale: 1-Not Important, 2-Somewhat Important, 3-Important, 4-Very Important Industry Description of Employers

Employers were asked to describe the industry which best described their organization. The three most represented industries consisted of $15(15.3 \%)$ from government, $13(13.3 \%)$ from landscape architecture, and $10(10.2 \%)$ from forestry employers. Other industries represented were: eight $(8.2 \%)$ agricultural production or industries; six (6.1\%) child care or development; five $(5.1 \%)$ each from education, lumber-wood products, and recreation; three (3.1\%) from banking, consulting and healthhospital-public health; two (2.0\%) from food processing and land management; and one 
(1.0\%) from fashion, hospitality, interior design, marketing, research, retail, and tourism.

All industries that hire or recruit Davis College graduates were represented in the respondents. Eleven (11.2\%) respondents indicated other as a industry description which included: three in urban forestry; two in social service; and one each for residential treatment, international development, land planning, wholesale marketplace, home builder, and automotive manufacturing (see Table 10).

Table 10

Industry Description of Employers

\begin{tabular}{lrr}
\hline & \multicolumn{2}{c}{ Industry Description } \\
\cline { 2 - 3 } & $N$ & $\%$ \\
\hline Government & 15 & 15.3 \\
Landscape Architecture & 13 & 13.3 \\
Forestry & 10 & 10.2 \\
Agricultural Production-Industries & 8 & 8.2 \\
Child Care-Development & 6 & 6.1 \\
Education & 5 & 5.1 \\
Lumber-Wood Products & 5 & 5.1 \\
Recreation & 5 & 5.1 \\
Banking & 3 & 3.1 \\
Consulting & 3 & 3.1 \\
Health-Hospital-Public Health & 3 & 3.1 \\
Food Processing & 2 & 2.0 \\
Land Management & 2 & 2.0 \\
Fashion & 1 & 1.0 \\
Hospitality & 1 & 1.0 \\
Interior Design & 1 & 1.0 \\
Marketing & 1 & 1.0 \\
Research & 1 & 1.0 \\
Retail & 1 & 1.0 \\
Tourism & 1 & 1.0 \\
Other & 11 & 11.2 \\
\hline
\end{tabular}




\section{Majors Employers Have Hired or Would Consider}

Respondents indicated which majors they have hired from and which majors they would consider hiring (see Table 11). The employers responding had hired all majors available in the Davis College of Agriculture, Forestry and Consumer Sciences. Combined respondents have hired 242 college graduates from the 18 majors. The greatest number of graduates hired from one major was 30 (30.6\%) from Forest Resources Management, followed by 28 (28.6\%) from Landscape Architecture, 19 (19.4\%) from Recreation, Parks and Tourism Resources, and 17 (17.3\%) from Wildlife and Fisheries. The least represented majors were three (3.1\%) Biochemistry responses, and two (2.0\%) responses for Textiles, Apparel and Merchandising.

Employers also responded to the majors from which they would consider hiring. All majors were represented in consideration for hiring. The responses ranged from 33 (33.7\%) respondents would consider hiring Forest Resources Management majors to 13 (13.3\%) respondents consider hiring Interior Design majors. 
Table 11

Majors Employers Have Hired or Would Consider

\begin{tabular}{|c|c|c|c|c|}
\hline & \multicolumn{2}{|c|}{ Hired } & \multicolumn{2}{|c|}{ Would Consider } \\
\hline & $N$ & $\%$ & $N$ & $\%$ \\
\hline Agribusiness Management \& Rural Development & 14 & 14.3 & 28 & 28.6 \\
\hline Agricultural \& Environmental Education & 16 & 16.3 & 27 & 27.6 \\
\hline Agronomy & 5 & 5.1 & 24 & 24.5 \\
\hline Animal \& Veterinary Sciences & 16 & 16.3 & 22 & 22.4 \\
\hline Basic Sciences & 14 & 14.3 & 27 & 27.6 \\
\hline Biochemistry & 3 & 3.1 & 20 & 20.4 \\
\hline Child Development \& Family Studies & 12 & 12.2 & 17 & 17.3 \\
\hline Environmental \& Natural Resource Economics & 11 & 11.2 & 26 & 26.5 \\
\hline Environmental Protection & 13 & 13.3 & 31 & 31.6 \\
\hline Forest Resources Management & 30 & 30.6 & 33 & 33.7 \\
\hline Horticulture & 14 & 14.3 & 25 & 25.5 \\
\hline Human Nutrition \& Foods & 7 & 7.1 & 18 & 18.4 \\
\hline Interior Design & 6 & 6.1 & 13 & 13.3 \\
\hline Landscape Architecture & 28 & 28.6 & 30 & 30.6 \\
\hline Recreation, Parks \& Tourism Resources & 19 & 19.4 & 20 & 20.4 \\
\hline Textiles, Apparel \& Merchandising & 2 & 2.0 & 12 & 12.2 \\
\hline Wildlife \& Fisheries Resources & 17 & 17.3 & 24 & 24.5 \\
\hline Wood Industries & 15 & 15.3 & 23 & 23.5 \\
\hline
\end{tabular}

\section{Number of Graduates Hired}

The number of Davis College of Agriculture, Forestry, and Consumer Sciences graduates hired by the respondents is reported in Table 12 . Of the 98 , the mean number of Davis College graduates hired was 2.66 with a standard deviation of 3.493 . The maximum number of graduates hired by one respondent was 20 and the minimum was zero (see Table 12). 
Table 12

Number of Graduates Hired

\begin{tabular}{lccccc}
\hline & $N$ & Minimum & Maximum & Mean & $S D$ \\
\hline $\begin{array}{l}\text { Number of Graduates } \\
\begin{array}{l}\text { Company has hired in } \\
\text { last 5 years }\end{array}\end{array}$ & 73 & 0 & 20 & 2.66 & 3.493 \\
\hline
\end{tabular}

Preparation Level of Davis College Graduates for Entry Level Employment

The final data analyses performed on responses from the questionnaire by employers was on the preparation level of Davis College graduates compared with graduates from other colleges. Respondents rated Davis College graduates on a scale of better prepared, equally prepared, and worse prepared. A response of never employed a graduate of the Davis College was provided for respondents if applicable. Responses were coded for data entry on the following scale: 1-better prepared, 2-equally prepared, 3-worse prepared, and 4-never employed a graduate of the Davis College. Fourteen (22.2\%) respondents indicated Davis College graduates were better prepared than NonDavis College graduates, 27 (42.9\%) were equally prepared, two $(3.2 \%)$ worse prepared, and twenty (31.7\%) of respondents had never employed a Davis College graduate. Frequencies were analyzed a second time after removal of the responses of never employed. The percentages reported were $32.6 \%$ better prepared, $62.8 \%$ equally prepared, and $4.7 \%$ worse prepared (see Table 13 ). 
Table 13

Preparation Level of Davis College Graduates for Entry Level Employment

\begin{tabular}{lcccccccr}
\hline & \multicolumn{2}{c}{$\begin{array}{c}\text { Better } \\
\text { prepared }\end{array}$} & \multicolumn{2}{c}{$\begin{array}{c}\text { Equally } \\
\text { prepared }\end{array}$} & \multicolumn{2}{c}{ Worse } & \multicolumn{2}{c}{$\begin{array}{c}\text { Never } \\
\text { employed }\end{array}$} \\
\cline { 2 - 9 } & $N$ & $\%$ & $N$ & $\%$ & $N$ & $\%$ & $N$ & $\%$ \\
\hline $\begin{array}{l}\text { Davis College graduates } \\
\text { compared to Non-Davis College } \\
\text { graduates }\end{array}$ & 14 & 22.2 & 27 & 42.9 & 2 & 3.2 & 20 & 31.7 \\
Comparison of employed & 14 & 32.6 & 27 & 62.8 & 2 & 4.7 & \\
\hline
\end{tabular}

Rating scale: 1-better prepared, 2-equally prepared, 3-worse prepared, 4- never employed

Respondents were asked what courses, other than technical subject matter, they thought would be most beneficial for students seeking employment with their company. The open-ended responses were grouped (see Appendix E) and five courses dominated the responses received. Respondents indicated that public speaking was the course that would be most beneficial for students. One respondent wrote, "Should require public speaking courses for all majors."

The second highest course recommended by respondents that would benefit students was communications courses. Several respondents made comments on communication courses and skills. One respondent wrote, "Communication skills are very important." Another said, "In a public service profession, students or graduates have to be able to communicate effectively. As a WVU alumni, I know I did not get enough communication classes when I was here '88-'92!' Another response was, "Grades are important, but not as important as the ability to communicate and get along with others." Respondents indicated that business, marketing, and writing courses would also be beneficial for students seeking employment. The writing courses included basic writing, business writing and technical writing. 
One employer and former graduate commented, "Three of the most important skills that are often lacking in today's college graduates are effective public speaking skills, strong writing abilities, and a willingness to make decisions independently. Too much emphasis is often placed on feelings rather that thoughts and on the use of technology as a replacement for good communication skills."

\section{Summary of Research Findings}

This research study was designed to determine the non-technical skills needed by students graduating from land-grant institutions to be employed in the agribusiness industry. Additionally, this study sought to determine the skills that will increase the chances of graduates in competing for employment. All majors in the Davis College were well represented by industry type and the majors which employers hire and would consider hiring. This study found the skills and traits important to employers for graduates' success. The level of preparation of graduates in various skills and abilities was determined by the responses from the questionnaire. Comparisons of Davis College graduates with graduates from other colleges were also presented. 


\section{CHAPTER V}

Summary, Conclusions, and Recommendations

Purpose of the Study

The purpose of this study was to determine the non-technical skills needed by students graduating from land-grant institutions to be employed in the agribusiness industry. Additionally, this study was designed to determine the skills that will increase the chances of graduates in competing for employment in the agribusiness industry. The target population for this study was firms who recruit or hire Davis College of Agriculture, Forestry and Consumer Sciences graduates. The accessible population consisted of 211 businesses, educational institutions, and government agencies that have recruited or hired graduates of the Davis College of Agriculture, Forestry and Consumer Sciences through Davis College Career Fairs within the past five years. The population consisted of firms from West Virginia, Maryland, Pennsylvania, Ohio, Virginia, Washington, DC, North Carolina, Connecticut, Delaware, Georgia, New York, New Jersey, Kansas, Wisconsin, and California.

The importance of industry input in preparing "Career Ready Graduates" is clear and well documented. Colleges have to be providing the courses that provide graduates with the skills and abilities to be successful in entry level employment.

The more that is known about competencies needed in agriculture careers and is incorporated into curriculum development, the more employable agriculture graduates will be in the marketplace. Additionally, the input from employers would provide a benchmark against which future students 
would be compared and serve as an assessment indicator. (Dick \& Carey, 1996, pp.67-68)

\section{Objectives of the Study}

Specific objectives for this study were:

1. To identify items of importance to employers for successful interviewing.

2. To determine the personality traits and life experiences that are important for success on the job.

3. To identify the communication skills, business skills and business abilities possessed by graduates of the Davis College as perceived by recruiters and employers of Davis College graduates.

4. To determine what communication skills, business skills, and business abilities employers deem important for entry level employment.

5. To identify the demographics of employers that recruit Davis College graduates based on the industry type, the majors they have hired, the majors these employers would consider hiring, and the number of graduates hired.

\section{Summary of Findings}

Two-thirds of respondents indicated that graduates were prepared for the communication skills of following instructions, one-on-one communications, and contributing to small groups. Slightly more than one-half of respondents indicated graduates were prepared for oral communication skills, expressing their ideas and thoughts, demonstrating effective verbal skills, and listening skills. Almost two-thirds of respondents indicated graduates were somewhat or not prepared in effective non-verbal skills, presentation skills, written skills, and giving instructions. Seven out of ten 
graduates were somewhat or not prepared for public speaking. Respondents rated the importance for entry level employees to possess these various communication skills and traits. More than nine out of ten employers rated the following skills and traits as important: effective verbal skills, oral communication, listening, following instructions, one-on-one communication, expressing thoughts and ideas, written skills, effective nonverbal skills and contributing in small groups. The remaining communication skills of public speaking, presentation skills, and giving instructions were important to more than seven out of ten respondents.

In the area of business skills, more than $80 \%$ of respondents said that graduates were prepared with computer skills. Slightly more than half responded that graduates were prepared for planning and completing projects. Almost one-half of respondents rated graduates prepared for needs assessment and time management skills. For the skills of decision-making and conflict resolution, two-thirds and three-fourths of respondents respectively rated graduates as somewhat or not prepared. Approximately three-fourths of employers rated all of the above business skills as important to graduates for entry level employment with more than two-thirds of respondents indicating time management and planning and completing projects skills were very important.

Almost three-fifths of respondents rated graduates as prepared for professional appearance and professional behavior. For the business abilities of leadership, selfevaluation, supervision, marketing, and management, slightly less than two-thirds of the employers rated graduates as somewhat or not prepared. When rating the importance of business abilities for graduates in entry level positions, nearly all the respondents rated professional behavior, leadership, and professional appearance as important. Self- 
evaluation, supervision and management abilities were rated important by two-thirds of respondents. Slightly less than one-half of employers rated marketing as important. When comparing Davis College graduates with Non-Davis College graduates in perceived preparation of business abilities, slightly more than one-third of respondents rated all graduates as prepared.

In regards to items of preference for initial consideration for an interview, respondents rated résumé length, references, and paper and font. Almost two-thirds of respondents prefer résumés one page in length, however all respondents would accept a one-page résumé. Two-page résumés would be accepted by nearly three-fourths of the employers. Two page résumés are preferred by one-fourth of the employers. For résumés more than two pages in length, $70 \%$ of respondents would accept them, but slightly more than one-fourth of respondents would reject. Two-thirds of employers prefer references included with a submitted résumé. When asked about the number of references included with the résumé, almost one-half of respondents preferred three or more references however $80 \%$ of respondents would accept fewer than three references.

Respondents rated the importance level of various items that contribute to successful interviewing with their companies. Eighty percent of respondents rated education, work experience and coursework as the most important items on a résumé. During the interview itself, nearly all of the employers rated eye contact, appearance, thorough and complete answers, a current revised résumé, and professional attire as the most important items for successful interviewing. Ninety-seven percent of the respondents rated eye contact and appearance as the highest items of importance dor the interview. 
Thirteen personality skills and traits were rated by respondents on level of importance to success in the job place. Nearly all of the respondents rated 12 of the 13 personality skills and traits as important. All of the respondents rated trustworthy, honest, good work ethic, motivated, and dependable as very important to success in the job place. The least important trait was exuding confidence, rated as important by $80 \%$ of the respondents.

Employers rated life experiences that may affect success of new employees in their organizations. Experiences were rated based on the level of importance to contributing to success of new employees. Career related employment, hands-on experiences, practical experiences, career-related internships, general work experience, and life experiences were rated as important by nearly $75 \%$ of the respondents. Slightly more than one-half of respondents rated community and volunteer programs as important. Approximately three-fourths of the employers rated the remaining experiences: participation in honors programs, active student club member, officer of a student club, labs, field trips, agricultural mechanics, and international experiences, as somewhat or not important.

The respondents' demographic characteristics were as follows: all industries were represented, all majors within the Davis College of Agriculture, Forestry and Consumer Sciences were represented by the respondents' having hired and considered these majors, and each respondent on average had hired over two Davis College graduates in the last five years.

The final question analyzed was the preparation level of Davis College graduates for entry level employment as compared to graduates of other schools or colleges. 
Twenty percent of respondents rated Davis College graduates as better prepared, $40 \%$ rated them as equally prepared, and slightly less than $40 \%$ of respondents had never employed a Davis College graduate.

\section{Conclusions}

Based upon the results of this study, the following conclusions were drawn:

1. Graduates were not prepared in the communication skills of oral communication, expressing ideas and thoughts, effective verbal skills, listening, effective nonverbal skills, presentation skills, written skills, giving instructions and public speaking.

2. Graduates were not prepared in the business skills of needs assessment, time management, decision-making, and conflict resolution.

3. Graduates were not prepared in the business abilities of leadership, self evaluation, supervision, marketing, and management.

4. The communication skills rated in this study were important to over $75 \%$ of the respondents.

\section{Recommendations}

Based upon the results of this study, the following conclusions were made:

1. Further research should be conducted to determine other skills important to employers and to the success of graduates.

2. This study should be replicated on additional firms who recruit and hire Davis College of Agriculture, Forestry, and Consumer Sciences graduates.

3. This study should be replicated annually to ensure industry input into the preparation of graduates for the work force. 
4. Consideration should be given to adding courses to the curriculum which will address the skills employers' desire in graduates.

5. Courses which teach many of the communication skills employers desire and find lacking in preparation, should be evaluated for consideration as required in the curriculum for all students of the Davis College of Agriculture, Forestry, and Consumer Sciences.

6. Funding should be acquired for additional faculty to expand and develop additional courses to better prepare graduates.

7. The Davis College's database of employers who recruit and hire graduates should be updated and maintained with current information including phone numbers and email addresses. 


\section{REFERENCES}

Andelt, L. L., Barrett, L. A., \& Bosshamer, B. K. (1997). Employer assessment of the skill preparation of students from the college of agricultural sciences and natural resources. NACTA Journal, 41(4), 47-53.

Ary, D., Jacobs, L. C., \& Razavieh, A. (2002). Introduction to research in education $\left(6^{\text {th }}\right.$ ed.). Belmont, CA: Wadsworth/Thomson Learning.

Bhaerman, R., \& Spill, R. (1988). A Dialogue on employability skills: How can they be taught? Journal of Career Development, 15(1), 41-52.

Blezek, A. G., \& Dillon, R. D. (1991). Perceptions of agribusiness leaders toward agricultural education in Nebraska. Journal of Agricultural Education, 32(2), 3439.

Brown, W. F., \& Fritz, S. M. (1993). Determining the breadth of leadership and human resource management/development offerings in post secondary departments of agricultural education. NACTA Journal, 37(3), 11.

Buck. L. L., \& Barrick, R. K. (1987). They're trained, but are they employable? Vocational Education Journal, 62(5), 29-31.

Coorts, G. D. (1987). Updating today’s college curriculum for tomorrow’s agriculture. NACTA Journal, 31(2), 20-21.

Cotton, K. (1993). Developing Employability Skills. Retrieved October 13, 2004, from http: //www.nwrel.org/scpd/sirs/8/c015.html

Dick, W., \& Carey, L. (1996). The systematic design of instruction (4 $4^{\text {th }}$ ed.). New York: Harper Collins College Publisher. 
Dillman, D. A. (2004). Mail and internet surveys: The total design method. New York: John Wiley \& Sons.

Gall, M. D., Borg, W. R., \& Gall, J. P. (1996). Educational research: An introduction (6 ${ }^{\text {th }}$ ed.). White Plains, NY: Longman.

Garton, B. L., Robinson, J. S., \& Campbell, J. L. (2004). Where are they today? A follow-up of agricultural education graduates. Proceeding of the AAAE North Central Agricultural Education Research Conference. (114-127), Lafayette, IN.

Graham, D. L. (2001). Are we preparing society ready graduates? Proceeding of the $28^{\text {th }}$ Annual National Agricultural Education Research Conference. (269-281).

Gregson, J. A., \& Bettis, P. J. (1991). Secondary trade and industrial education work values instruction: Emancipatory or indoctrinal? Paper presented at the American Vocational Association Convention, Los Angeles, CA. December 1991. (ED 341 781).

Hasenauer, J., (2001). Academy shows ins, outs of ag [Electronic version]. North Platte Telegraph, 1-2.

Klein, M. L. (1990). Southern California food and agricultural firms. NACTA Journal, 34(2), 30-34.

Kunke, H. O., Maw, I. L., \& Skaggs, C. L. (1996). Revolutionizing higher education in agriculture. Ames, Iowa: Robson \& Associates.

Lankard, B. A. (1995). Business and education partnerships. Paper presented to the Educational Resources Information Center. Columbus, Ohio. September 1995. 
Long, G. A., Straquadine, G., \& Campbell, W. F. (1992). Plant science alumni rate their education based upon entry level professional experience. Journal of Natural Resources and Life Science Education, 21(1).

Merritt, R. H., \& Hamm, M. W. (1994). Agricultural and natural resources curriculum renewal at Cook College, Rutgers University. Journal of Natural Resources and Life Science Education, 23(2).

Morrill Land-Grant Act of 1862. $37^{\text {th }}$ Congress Session II, Chapter 130. July 2, 1862, 12, 504.

Radhakrishna, R. B., \& Bruening, T. H. (1994). Pennsylvania study: employee and student perceptions of skills and experiences needed for careers in agribusiness. NACTA Journal, 38(1), 15-18.

Robinson, J. P., Shaver, P. R., \& Wrightsman, L. S. (1991). Measures of personality and social psychological attitudes. New York: Academic Press.

Scanlon, D. C., Bruening, T. H., \& Cordero, A. (1996). An industry perspective on changes needed in agricultural education curricula. Journal of Agricultural Education, 37(2), 17-23.

Secretary's Commission on Achieving Necessary Skills. What work requires of schools. A SCANS Report for America 2000. Washington, DC: U.S. Department of Labor, June 1991

Singh, S. P., Ekanem, E., Tegegne, F., \& Muhammed, S. (2000). A profile of food and agricultural firms in Tennessee: An industry perspective on attributes and skills needed by college graduates in agribusiness and agricultural economics. A paper presented at the annual meeting of the SAEA, Orlando, FL, Feb. 2-6, 2000. 
Spotanski, D. R. \& Foster, R. M. (1989). Agribusiness skills required by agriculture students as perceived by Nebraska vocational agriculture instructors and agribusiness managers. Journal of Agricultural Education, 30(3), 2-6.

Slocombe, J. W. \& Baugher, E. E. (1988). Revitalizing agricultural curricula. NACTA Journal, 32(3), 8-10.

W. K. Kellogg Foundation. (1994). Visions of change in higher education. W.K. Kellogg Foundation: Battle Creek, Michigan.

Wentling, R. M. (1987). Employability skills: The role of business education. Journal of Education for Business, 62(7), 313-317.

West Virginia University. (2003). West Virginia University Undergraduate Catalog 2003-2005. West Virginia University, Purinton House: WV, 1(2) 285. 
APPENDICES 


\section{APPENDIX A}

Career Fair Interview Questions 


\section{QUESTIONS FOR CAREER FAIR RECRUITERS}

1) What are the first things you look for in a résumé and/or application?

2) Are there any do's or don'ts for writing résumés that you would share with potential employees if you could?

3) What are the top 5 skills you value most in prospective employees?

4) What are the top 5 traits you value most in prospective employees?

5) If you have 2 candidates that have identical technical skills and meet all the qualifications, what are the skills or traits that will make your decision?

6) Are there any skills that you have found missing or lacking in recent applicants or new employees?

7) What are the skills that you believe are critical for a new employee's success in the workplace?

8) Are there any skills or traits that benefit employees in their progression in the workplace? 
9) What are the skills or traits that may hinder a new employee's advancement in your company?

10) Are there any skills that you have found you must provide internal training for new hires?

11) If there was one course that should be taught at the university level to prepare graduates for careers, what would it be? 


\section{APPENDIX B}

Cover Letter to Research Population 
February 21, 2005

$<$ Name $>$

$<$ Add $>$

$<$ City $><$ State $><$ Zip $>$

\section{Dear $<$ NAME $>$ :}

I am conducting a research study to determine the skills and traits needed by graduates of the West Virginia University Davis College of Agriculture, Forestry and Consumer Sciences to secure employment. Specifically, I am gathering information from employers who have attended the Davis College Biannual Career Fairs over the past ten years. The results of the study will be used to prepare a thesis to partially fulfill the requirements for a Master of Science Degree in Agricultural and Environmental Education.

The enclosed questionnaire includes questions on traits and skills needed for successful interviewing with your company, the level of preparation and importance of skills and competencies for entry level employees, desired personality traits, the importance of certain experiences on employment, and basic demographics of your company. Please read the instructions carefully for each section and respond accordingly. Although your participation is voluntary, I am asking you to please take a few minutes of your time to fill out the questionnaire. You may skip any question you are not comfortable answering. Please be assured that all information will be held as confidential as possible. You will notice a code number at the bottom of the left-hand column of the questionnaire. This code will be used to identify non-respondents for follow-up and will be destroyed before data are analyzed.

Enclosed with the questionnaire is a business reply envelope for your convenience. If you could please return the completed questionnaire by March 7, 2005, I will be greatly appreciative.

Thank you in advance for your cooperation.

Sincerely,

Thomas H. Brand III

Graduate Teaching Assistant
Dr. Dennis K. Smith

Associate Dean
Dr. Stacy A. Gartin

Professor \& Chair 
APPENDIX C

Questionnaire 


\section{Non-technical Skills and Traits Needed To be Career Ready Graduates}

Please rate (circle) each of the following items on their importance for successful interviewing with your company. Use the following four-point scale of $4=$ "very important," 3 = "important," 2 = "somewhat important," and 1 = "not important."

\section{Letters}

Application letter

Follow-up letter

\section{Very}

Important Important

$\begin{array}{ll}4 & 3 \\ 4 & 3\end{array}$

\section{Résumé}

Education

Coursework/specialization

Job objective

Grade point average

Work experience

Dates of prior employment

Internships

Hobbies/interests

Personal characteristics

$\begin{array}{ll}4 & 3 \\ 4 & 3 \\ 4 & 3 \\ 4 & 3 \\ 4 & 3 \\ 4 & 3 \\ 4 & 3 \\ 4 & 3 \\ 4 & 3\end{array}$

Somewhat
Important

2

2
Not

Important Applicable

2
2
2
2
2
2
2
2
2

1

0

1

o

\section{Interview}

Firm handshake

Professional attire

Appearance

Current/revised résumé

Eye contact

Questions for interviewer

Knowledge of company

Assertiveness

Thorough/complete answers

4

4

4

4

4

4

4

4

4

$\begin{array}{ll}1 & 0 \\ 1 & 0 \\ 1 & 0 \\ 1 & 0 \\ 1 & 0 \\ 1 & 0 \\ 1 & 0 \\ 1 & 0 \\ 1 & 0\end{array}$

3
3
3
3
3
3
3
3
3

$\begin{array}{lll}2 & 1 & 0 \\ 2 & 1 & 0 \\ 2 & 1 & 0 \\ 2 & 1 & 0 \\ 2 & 1 & 0 \\ 2 & 1 & 0 \\ 2 & 1 & 0 \\ 2 & 1 & 0 \\ 2 & 1 & 0\end{array}$


Please rate (circle) the following items on level of preference for initial consideration or review of qualifications before extending a personal interview for the position.

\begin{tabular}{lccc} 
& Prefer & Accept & Reject \\
\cline { 2 - 4 } 1 page résumé & $\mathbf{3}$ & $\mathbf{2}$ & $\mathbf{1}$ \\
2 page résumé & $\mathbf{3}$ & $\mathbf{2}$ & $\mathbf{1}$ \\
More than 2 page résumé & $\mathbf{3}$ & $\mathbf{2}$ & $\mathbf{1}$ \\
References included & $\mathbf{3}$ & $\mathbf{2}$ & $\mathbf{1}$ \\
Fewer than 3 references & $\mathbf{3}$ & $\mathbf{2}$ & $\mathbf{1}$ \\
3 or more references & $\mathbf{3}$ & $\mathbf{2}$ & $\mathbf{1}$ \\
Fine quality paper & $\mathbf{3}$ & $\mathbf{2}$ & $\mathbf{1}$ \\
Colored paper & $\mathbf{3}$ & $\mathbf{2}$ & $\mathbf{1}$ \\
Colored font type & $\mathbf{3}$ & $\mathbf{2}$ & $\mathbf{1}$
\end{tabular}

Listed below are personality skills/traits which may or may not be important to success in the job place. Please rate (circle) each personality skills/traits on the level of importance for success in your company using the scale of: $4=$ "very important," $3=$ "important," 2 = "somewhat important," and $1=$ "not important."

\section{Very Important}

Hardworking

Team player

Motivated

Dedicated

Honest

Trustworthy

Organized

Dependable

Shows initiative

Good work ethic

Works independently

Exudes confidence

Hardworking

4
4
4
4
4
4
4
4
4
4
4
4
4

4

4

4

4

4

4

4

4

4

4

\section{Somewhat Important}

2

2

2

2

2

2

2

2

2

2

2

2

2

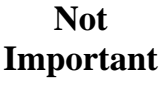

1

1

1

1

1

1

1

1

1

1

1

1

1

\section{Not Applicable}

0

o

0

0

0

0

0

0

0

o

0

0

0 
Listed below are experiences that may affect the success of new employees in your organization. Please rate (circle) how important you feel these experiences are to your entry level employees using the scale of scale of 4 = "very important," 3 = "important," 2 = "somewhat important," and $1=$ "not important."

$\begin{array}{ccccc}\begin{array}{c}\text { Very } \\ \text { Important }\end{array} & \text { Important } & \begin{array}{c}\text { Somewhat } \\ \text { Important }\end{array} & \begin{array}{c}\text { Not } \\ \text { Important }\end{array} & \begin{array}{c}\text { Not } \\ \text { Applicable }\end{array}\end{array}$

$\begin{array}{llllll}\text { Life experiences } & \mathbf{4} & \mathbf{3} & \mathbf{2} & \mathbf{1} & \mathbf{0} \\ \text { Hands-on experiences } & \mathbf{4} & \mathbf{3} & \mathbf{2} & \mathbf{1} & \mathbf{0} \\ \text { Practical experiences } & \mathbf{4} & \mathbf{3} & \mathbf{2} & \mathbf{1} & \mathbf{0} \\ \text { Career-related internships } & \mathbf{4} & \mathbf{3} & \mathbf{2} & \mathbf{1} & \mathbf{0} \\ \text { Career-related employment } & \mathbf{4} & \mathbf{3} & \mathbf{2} & \mathbf{1} & \mathbf{0} \\ \text { Field trips } & \mathbf{4} & \mathbf{3} & \mathbf{2} & \mathbf{1} & \mathbf{0} \\ \text { Labs } & \mathbf{4} & \mathbf{3} & \mathbf{2} & \mathbf{1} & \mathbf{0} \\ \text { Agricultural mechanics } & \mathbf{4} & \mathbf{3} & \mathbf{2} & \mathbf{1} & \mathbf{0} \\ \text { General work experience } & \mathbf{4} & \mathbf{3} & \mathbf{2} & \mathbf{1} & \mathbf{0} \\ \text { Officer of student club } & \mathbf{4} & \mathbf{3} & \mathbf{2} & \mathbf{1} & \mathbf{0} \\ \text { Active student club member } & \mathbf{4} & \mathbf{3} & \mathbf{2} & \mathbf{1} & \mathbf{0} \\ \text { International experiences } & \mathbf{4} & \mathbf{3} & \mathbf{2} & \mathbf{1} & \mathbf{0} \\ \begin{array}{l}\text { Participation in Honors } \\ \quad \text { Programs }\end{array} & \mathbf{4} & \mathbf{3} & \mathbf{2} & \mathbf{1} & \mathbf{0} \\ \text { Community/volunteer } & & & & & \mathbf{0} \\ \quad \text { programs } & \mathbf{4} & \mathbf{3} & \mathbf{2} & \mathbf{1} & \end{array}$

Please rate (circle) how well college graduates are PREPARED for entry level jobs in your organization using the scale of scale of $4=$ "very well prepared," $3=$ "prepared," 2 = "somewhat prepared," and $1=$ "not prepared." Also, in the importance column, please indicate how IMPORTANT these skills or competencies are for an ENTRY LEVEL EMPLOYEE of your organization using the scale of scale of $4=$ "very important," $3=$ "important," 2 = "somewhat important," and 1 = "not important."

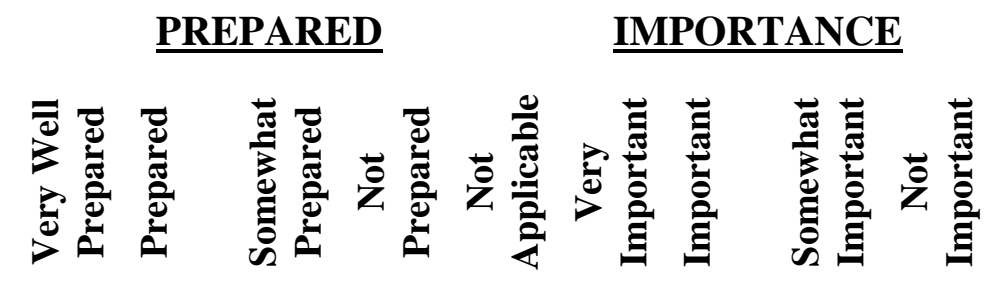

\section{Communication}

Effective verbal skills

Effective nonverbal skills

Oral communication

$\begin{array}{lllllllll}4 & 3 & 2 & 1 & 0 & 4 & 3 & 2 & 1 \\ 4 & 3 & 2 & 1 & 0 & 4 & 3 & 2 & 1 \\ 4 & 3 & 2 & 1 & 0 & 4 & 3 & 2 & 1\end{array}$




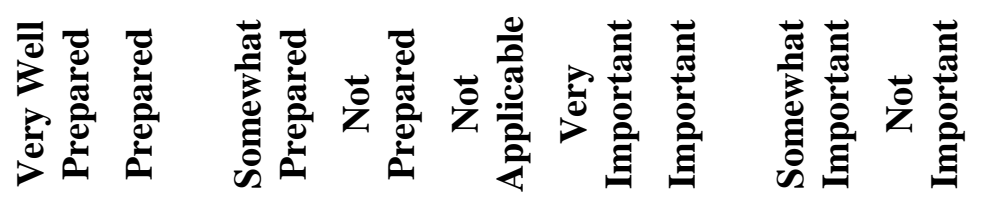

Written skills

Public speaking

Presentation skills

Expressing ideas/thoughts

43

4

2

10

$\begin{array}{lllll}4 & 3 & 2 & 1 & 0\end{array}$

$\begin{array}{llll}4 & 3 & 2 & 1\end{array}$

Listening

Contribute in small groups

Giving instructions

Following instructions

One-on-one communication

4

$\begin{array}{llll}4 & 3 & 2 & 1\end{array}$

$\begin{array}{llll}4 & 3 & 2 & 1\end{array}$

$\begin{array}{llll}4 & 3 & 2 & 1\end{array}$

43

43

Based on the communication

$\begin{array}{lllll}4 & 3 & 2 & 1 & 0\end{array}$

skills listed above, how well are

Davis College graduates

prepared?

\section{Business Skills}

Time management

Planning and completing projects

Conflict resolution

Decision-making

Computer

Needs assessment

$\begin{array}{lllllllll}4 & 3 & 2 & 1 & 0 & 4 & 3 & 2 & 1 \\ 4 & 3 & 2 & 1 & 0 & 4 & 3 & 2 & 1 \\ 4 & 3 & 2 & 1 & 0 & 4 & 3 & 2 & 1 \\ 4 & 3 & 2 & 1 & 0 & 4 & 3 & 2 & 1 \\ 4 & 3 & 2 & 1 & 0 & 4 & 3 & 2 & 1 \\ 4 & 3 & 2 & 1 & 0 & 4 & 3 & 2 & 1\end{array}$

Based on the business skills

listed above, how well are Davis

College graduates prepared?

\section{Business Abilities}

Supervision

Marketing

Management

Leadership

Self evaluation

Professional appearance

$\begin{array}{lllllllll}4 & 3 & 2 & 1 & 0 & 4 & 3 & 2 & 1 \\ 4 & 3 & 2 & 1 & 0 & 4 & 3 & 2 & 1 \\ 4 & 3 & 2 & 1 & 0 & 4 & 3 & 2 & 1 \\ 4 & 3 & 2 & 1 & 0 & 4 & 3 & 2 & 1 \\ 4 & 3 & 2 & 1 & 0 & 4 & 3 & 2 & 1 \\ 4 & 3 & 2 & 1 & 0 & 4 & 3 & 2 & 1\end{array}$


$\begin{array}{lllllll}\text { Based on the business abilities } & 4 & 3 & 2 & 1 & 0\end{array}$

listed above, how well are Davis

College graduates prepared?

Which industry best describes your company? (Please choose one answer.)
- Agricultural
$\circ$ Land Management
Production/Industries
- Lumber/Wood Products
- Banking
○ Marketing
- Consulting
- Merchandising
- Child Care/Development
- Nursery/Greenhouse
- Communications
- Nutrition
- Economics/Development
o Policy
- Education
- Public Relations
- Fashion
- Recreation
- Food Processing
- Research
- Forestry
- Retail
- Government
- Technical
- Health/Hospital/Public
- Tourism Health
- Utilities
- Hospitality
- Wildlife/Fisheries
o Interior Design
o Other
- Insurance
- Landscaping

From the following list, please choose the majors you have HIRED graduates from, and which majors would you CONSIDER when hiring graduates. (Please select all that apply.)

Agribusiness Mgmnt \& Rural Development

HIRED CONSIDER

Agricultural \& Environmental Education

Agronomy

Animal \& Veterinary Sciences

Basic Sciences

Biochemistry

Child Development \& Family Studies

Environmental \& Natural Resource

Economics

Environmental Protection

Forest Resources Management 
Horticulture

Human Nutrition \& Foods

Interior Design

Landscape Architecture

Recreation, Parks \& Tourism Resources

Textiles, Apparel \& Merchandising

Wildlife \& Fisheries Resources

Wood Industries

How many graduates of the Davis College of Agriculture, Forestry and Consumer Sciences of West Virginia University have you hired in the last 5 years?

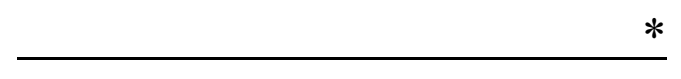

*If answer is none, then skip the next question.

Compared with graduates from other colleges, how well are graduates from the Davis College prepared for entry level employment?

0 Better prepared

0 Equally prepared

0 Worse

o Never employed a graduate of the Davis College

Besides technical subject matter, what type courses do you believe would be most beneficial for students seeking employment with your company?

Please share additional comments below regarding the hiring of career ready graduates which may or may not be included in this questionnaire.

Thank you very much for completing this survey. By doing so, you help us continually improve the curriculum offered at the Davis College of Agriculture, Forestry and Consumer Sciences and the preparedness of your future employees. 


\section{APPENDIX D}

Follow-up Cover Letter to Research Population 
March 8, 2005

$<$ Name $>$

$<$ Add $>$

$<$ City $><$ State $><$ Zip $>$

Dear $<$ NAME $>$ :

We recently mailed you a survey concerning a thesis study we are conducting to determine the skills and traits needed by graduates of the West Virginia University Davis College of Agriculture, Forestry and Consumer Sciences to secure employment.

As of yet, we have not received your response. If you have responded let us thank you in advance. If not, please take a few minutes to fill out the enclosed form. Your participation is voluntary, but is also vital to the results of this research effort. The data received to date from other responses looks to be quite informative and we would like to add your responses to the overall effort.

Enclosed with the questionnaire is a business reply envelope for your convenience. If we might have your responses by March 15, 2005, we would be most appreciative.

Thank you in advance for your cooperation.

Sincerely,

Thomas H. Brand III

Graduate Teaching Assistant
Dr. Stacy A. Gartin

Professor \& Chair 


\section{APPENDIX E}

Courses Beneficial to Students 
The following courses were stated by respondents as beneficial to graduates seeking entry level employment with their companies:

\begin{tabular}{lc} 
Course & Number of Respondents \\
\cline { 2 - 2 } Public Speaking & 14 \\
Communications & 13 \\
Business & 10 \\
Marketing & 8 \\
Writing (Business and technical) & 8 \\
Business Management & 5 \\
People/Client Management & 4 \\
Time Management & 3 \\
Conflict Resolution & 3 \\
Finance & 3 \\
Accounting & 3 \\
Leadership & 2 \\
Sales & 2 \\
Program Planning & 2 \\
Extension Issues/Trends & 2 \\
Power Point & 2 \\
Public Administration & 2
\end{tabular}




\section{APPENDIX F}

Comments for All Divisions 
The following comments were made by employers from government agencies:

"Because we are the National Park Service, almost everyone hired, even into specialist jobs will at some time or another find themselves speaking or presenting information. It is the nature of our jobs to be prepared to share information with the visiting public, other professionals or the media. To that end, communications skills are critical. The ability to speak intelligently on your subject, yet make it understandable to the audience you have at the moment is very important. Writing and other non-verbal skills also play an important part in our agency. It cannot be stressed enough that these skills will do nothing but help in the job hunting process. It can start with something as simple as a firm handshake and direct eye contact. As a federal agency, we encourage volunteering in the form of projects and internships on the student's related area of study. Not only does the agency benefit from the work completed by the student, the student benefits from the time volunteered. All volunteer time looked at by government hiring officials as valid work experience, showing that the student gained experience and made valuable use of their time during the time volunteered. It is a benefit to the student when attempting to obtain a position with the National Park Service to put in volunteer time and/or work seasonal positions. It looks good on an application.

"Important for students to work in their field during the summers."

"We need employees with a strong science background, they need to be ready to learn the skills they need to do the job." 
"Our USDA agency requires mobility within the United States. We encountered reluctance on the part of WVU graduates to relocate to other states where job opportunities exist. Since mobility is a condition of employment, we have not been able to attract WVU graduates."

"Three of the most important skills that are often lacking in today's college graduates are effective public speaking skills, strong writing abilities, and willingness to make decisions independently. Too much emphasis is often placed on feelings rather that thoughts and on the use of technology as a replacement for good communications skills. We also require absolute integrity!”

"Graduates need to realize they need experience in their field instead of spending summers working at Wal Mart. There is a need to network with in state agencies. Don't know students, such a need for students to work in field they want to go into. We nurture and educate potential full time employees. Network with professionals!”

"All individuals that we hire must test and then they are placed on a register according to their scores.”

“During our visit@ career fair the students were grossly unprepared, disshelved and poor communicators with a few exceptions. Contact PSU - they run a decent program for students. It's a 1 credit requirement." 


\section{APPENDIX G}

\section{Comments for Division of Resource Management}


The following comments were made by employers from industries who hire graduates from the Division of Resource Management:

"Subject matter can be learned, communication skills and etiquette are a must!"

"Should require public speaking courses for all majors."

"An understanding of technical subject matter is very important. However, this organization focuses more on degrees and GPA. A broad subject base is important including courses in animal science and agronomy. Graduates need to be prepared to sell themselves both in the "formal" interview and in the "informal" or "getting to know you" part of the interview process. Graduates also need to be familiar with preparation of KSA's (knowledge, skills, \& abilities)."

"There is a bit of a culture shock when transitioning from the college life to the real world. Graduates need to realize that attitudes and impressions can make or break your career."

"It seems as though the term "career-ready" means computer proficiency. In the business and practice of landscape architecture, the skills and practical knowledge takes years to develop. We look for graduates who can think, draw, and design; organize their thoughts (and portfolio) as well as technical computer skills. I would hire a good designer with average computer skills over a computer technician with poor design skills. 
Some of the problems we have had with recent entry-level employees can be attributed more to modern culture, than a failing of their education."

"Graduates need to be prepared to fill low level positions and work their way up as their qualifications and skills allow."

"The questionnaire was well developed and covered the important aspects of hiring, good luck." 


\section{APPENDIX H}

Comments for Division of Family and Consumer Sciences 
The following comments were made by employers from industries who hire graduates from the Division of Family and Consumer Sciences:

"For the position of teacher, I prefer to hire people with education in early childhood or education, but for the aides, I look for experience with children and good demeanor with people and children.”

"More practical work experience, more time in community businesses."

"For an industry as unique as fashion work and hands on experience is what it is all about. Any background is acceptable, the initiative and determination a person has makes the difference."

"In general, I find today's graduates portray a sense of “entitlement" vs. earning a career. The overall work ethic is not conducive to the needs of companies who require employees to have good customer service along with standards of productivity." 
APPENDIX I

Comments for Division of Forestry 
The following comments were made by employers from industries who hire graduates from the Division of Family and Consumer Sciences:

"We appreciate the opportunity to attend career fairs. I have hired two students this year."

"Grades are important, but not as important as the ability to communicate and get along with others."

"From my experience, I notice most graduates want to begin working in management and don't have much ambition to begin work in the field, learn and work their way up."

"Communication skills are very important."

"In a public service profession, students or graduates have got to be able to communicate effectively. As a WVU alumni, I know I did not get enough communication classes when I was here '88-'92.”

"Students should be reminded that there is a lot to learn in a career that college prepares you for. Be open-minded about learning.” 
"We have begun hiring interns from WVU, which we see as future employees. What is discouraging is the school rarely reaches out to us. Typically we have initiated all interactions. Then after various guest lecture visits and meetings with the department, we still have little contact. As an alumnus, I want to hire WVU kids, but Clemson, VT, even Allegheny CC make it easier for us. It is hard to fight my peers to continue to invest time in WVU. The professors and staff really need to reach out to more than one or two companies who finance them. We are very generous to schools that we get involved in, but we are not large enough to donate 10's of thousands of dollars." 


\section{APPENDIX J}

Comments for Division of Animal and Veterinary Sciences 
The following comments were made by employers from industries who hire graduates from the Division of Animal and Veterinary Sciences:

"Students need to understand that if they are to advance at the pace they desire, they need to be more mobile (willingness to relocate). The associates in our company that are advancing the quickest are the ones willing to move.”

"Our plant is a poultry plant and this is a lot of direct supervision of people. There is also a high count for non-productive time. We need people who are willing to work and show themselves as a leader but also be part of the team." 
VITA

\section{Thomas H. Brand III}

April 2003-May 2004

May-August 2004

August 2004

August 2004-May 2005

May 2005
Undergraduate GIS Research Technician

Natural Resource Analysis

Division of Resource Management

Supervisor: Dr. Jerry Fletcher

West Virginia University

Morgantown, West Virginia

Undergraduate Teaching Assistant

Agricultural \& Environmental Education

Supervisor: Dr. Stacy A. Gartin

West Virginia University

Morgantown, West Virginia

Bachelor of Science

Agribusiness Management \& Rural Development

West Virginia University

Morgantown, West Virginia

Graduate Teaching Assistant

Agricultural \& Environmental Education

Supervisor: Dr. Stacy A. Gartin

West Virginia University

Morgantown, West Virginia

Master of Science

Agricultural \& Environmental Education

West Virginia University

Morgantown, West Virginia 